\title{
Respiratory syncytial virus vaccine development
}

\author{
Julia L Hurwitz \\ Department of Infectious Diseases, St Jude Children's Research Hospital, 262 Danny Thomas \\ Place, Memphis, TN 38105, USA \\ Department of Microbiology, Immunology and Biochemistry, University of Tennessee, Memphis, \\ TN, USA
}

\begin{abstract}
Respiratory syncytial virus (RSV) is the leading cause of lower respiratory tract viral disease in infants and young children. Presently, there are no explicit recommendations for RSV treatment apart from supportive care. The virus is therefore responsible for an estimated 160,000 deaths per year worldwide. Despite half a century of dedicated research, there remains no licensed vaccine product. Herein are described past and current efforts to harness innate and adaptive immune potentials to combat RSV. A plethora of candidate vaccine products and strategies are reviewed. The development of a successful RSV vaccine may ultimately stem from attention to historical lessons, in concert with an integral partnering of immunology and virology research fields.
\end{abstract}

\section{Keywords}

antibody-mediated protection; formalin-inactivated vaccine; immunopathology; pediatric vaccine; prime-boost strategies; respiratory syncytial virus vaccines; T-cell-mediated protection; vaccine vectors

\section{Respiratory syncytial virus: the disease}

Respiratory syncytial virus (RSV) is the most common cause of lower respiratory tract infections in young children and is responsible for an estimated 160,000 deaths annually worldwide. In a single year, approximately 34 million episodes of RSV-associated lower respiratory tract infections may occur in children under the age of 5 years, and among these, $10 \%$ may require hospitalization [1]. Infant hospitalization costs may well exceed US $\$ 400$ million annually in the USA alone [2-12]. For patients with bronchiolitis and pneumonia, RSV has been identified as the etiologic agent in as many as 90 and $50 \%$ of cases, respectively $[9,10]$.

Newborn infants are partially protected from disease by maternal RSV-specific neutralizing antibodies, but this protection is not long lasting [13-16]. Infants are at particularly high risk for RSV-associated morbidity and mortality between 2 and 4 months of age when maternal antibodies have fallen and have not yet been replaced by an endogenous antibody response $[14,17]$. RSV infections usually occur in the first year after birth and by the second year,

(C) 2011 Expert Reviews Ltd

Tel.: +1 901595 2464, Fax: +1 901595 3099, julia.hurwitz@ stjude.org.

Financial \& competing interests disclosure

The authors have no other relevant affiliations or financial involvement with any organization or entity with a financial interest in or financial conflict with the subject matter or materials discussed in the manuscript apart from those disclosed.

No other writing assistance was utilized in the production of this manuscript. 
90\% of individuals will have been infected at least once [3]. Particularly prone to RSV infection are individuals born prematurely, of low birth weight and/or with congenital cardiopulmonary defects, but the majority of serious RSV infections occur among infants with no known risk factors. Individuals with underlying immunodeficiencies (e.g., bone marrow transplant recipients) and the elderly are also at high risk for RSV disease [18-21] and HIV-1-infected children shed RSV for remarkably long periods [6,22-24].

Respiratory syncytial virus is usually spread by droplets, direct contact or fomites. Several days (2-8) after viral infection, upper respiratory tract symptoms may occur (e.g., rhinorrhea, cough and sneezing). There may also be a loss of appetite and low-grade fever. Within 1-3 days following the onset of rhinorrhea, the virus and associated symptoms may spread to the lower respiratory tract. Severe bronchiolitis may occur, leading to airway blockage and respiratory distress. As an aftermath to RSV infection, airway hyperresponsiveness and obstruction (e.g., asthma and wheezing) can continue for many years. Debates are ongoing as to whether these long-term symptoms are caused by RSV [25] or define a predisposition that exacerbates RSV disease [3,17,26,301].

The first RSV infection is most severe and reinfections are common, particularly of the upper respiratory tract. In a clinical study when adults were deliberately challenged repeatedly with RSV, infections occurred in at least a quarter of the participants per challenge. Mild symptoms demonstrated that pre-existing immune responses did not afford complete protection $[6,27,28]$.

There are no clear recommendations for treatment of RSV apart from supportive care. Ribavirin is sometimes prescribed, but this drug is expensive and is not certain to improve outcome [5,29]. A new strategy for RSV control involving siRNA is now in early stages of clinical development [28]. As prophylaxis for RSV infection, a monoclonal antibody against a highly conserved RSV F epitope has been used (Synagis ${ }^{\circledR} /$ palivizumab [MedImmune, Gaithersburg, MD, USA]). This antibody has significantly reduced severe disease in highrisk infants [30]. In premature infants without chronic lung disease, the efficacy of Synagis/ palivizumab has been as high as $80 \%$ [31]. A new product with a similar specificity was recently developed by MedImmune (motavizumab) to replace Synagis/palivizumab, but tests did not support superiority and development of the new product for licensure has been discontinued [302]. Prophylaxis is not available to many who need it due to the cost and logistics of injections. It is generally prescribed for individuals with predetermined risk factors, and as stated earlier, risk factors are identified in only a fraction of susceptible children. In developing countries, constraints in infrastructure and funding further impede access [32]. Clearly, further development of RSV vaccines and therapies is warranted, and novel successful products could have an enormous positive impact on human health.

\section{RSV: the virus}

Respiratory syncytial virus is a negative-strand nonsegmented RNA virus of the family Paramyxoviridae, the subfamily Pneumovirinae and the genus Pneumovirus [17]. There are two subtypes, A and B. Virus size is pleiomorphic, typically $100-350 \mathrm{~nm}$ yet filaments may be as long as $10 \mu \mathrm{m}$. There are ten viral genes that are transcribed sequentially into separate mRNAs by the viral polymerase. Genes are linearly ordered from the $3^{\prime}$ to $5^{\prime}$ end of the negative-sense RNA genome. On the $3^{\prime}$ end are genes NS1, NS2 (putative nonstructural proteins 1 and 2, anti-inflammatory proteins), $N$ (nucleoprotein) and $P$ (phosphoprotein, a cofactor in RNA synthesis). These are followed by $M$ (matrix protein), $S H$ (small hydrophobic protein, a nonessential protein that may function as a pentameric ion channel $[3,33]), G$ (a type II integral membrane attachment glycoprotein), and $F$ (a type I integral membrane fusion protein). Most 5' are $M 2$ (a gene that encompasses two open-reading 
frames encoding M2-1 and M2-2, supportive of mRNA transcription and the balance between RNA replication and transcription) and $L$ (large protein, the major polymerase) $[3,17]$.

$\mathrm{G}$ and $\mathrm{F}$ proteins comprise the major glycoprotein spikes on the viral membrane and are major targets of neutralizing antibodies. SH is a third integral membrane protein, but is not required for efficient viral growth in vitro or in vivo. The G protein is approximately 300 amino acids in length, but is heavily glycosylated with several $\mathrm{N}$-linked glycosylation sites and perhaps as many as $25 \mathrm{O}$-linked glycosylation sites, yielding a glycoprotein of molecular weight approximately $90 \mathrm{kDa}[3,17]$. RSV G also exists as a secreted protein product owing to an alternative initiation codon in the coding region of the transmembrane domain $[6,34]$. Some researchers suggest that secreted product may act as a decoy to block the host's G-specific neutralizing antibody response $[6,35,36]$. The $F$ protein is approximately 500 amino acids in length and glycosylated much less heavily than G, yielding a 70-kDa glycoprotein product. $\mathrm{F}$ protein is first synthesized as an inactive $\mathrm{F}_{0}$ precursor that assembles into a homotrimer [17]. The precursor is sensitive to cleavage by a furin-like intracellular protease in the trans-golgi of an infected cell (although full cleavage is not required for transport of $\mathrm{F}$ to the infected cell surface [37,38]). Three products of cleavage are $F_{2}$, p27 and $F_{1} . F_{1}$ contains the transmembrane domain at one end, two heptad repeats (HRA and HRB), and a hydrophobic fusion peptide at the opposite end. The $\mathrm{F}_{1}-\mathrm{F}_{2}$ disulfide linkage forms the active molecule essential for virus/cell fusion or cell/cell fusion (syncytia formation) [39]. RSV replicates almost exclusively in the mammalian respiratory tract [6] where the furin-like protease is synthesized. Apart from facilitating virus fusion, the RSV F protein is also capable of signaling through Toll-like receptor (TLR)-4 and CD14 $[40,41]$. This signaling may induce proinflammatory cytokines including interferons with antiviral activities. By contrast, the G, NS-1 and NS-2 proteins may in some cases downregulate inflammatory events $[3,17,42]$.

The virus life cycle typically begins by attachment of the $\mathrm{G}$ glycoprotein to the mammalian host plasma cell membrane ( $\mathrm{F}$ can also facilitate attachment), followed by F-mediated fusion. Paramyxoviruses typically fuse at the cell surface. Some siRNA studies have suggested that clathrin-mediated endocytosis and early endosomes may also play a role in RSV infectivity [3,43]. The cellular targets of $G$ and F proteins are not fully defined. G protein can bind glycosaminoglycans such as heparin sulfate and chondroitin sulfate B as well as C-type lectins such as surfactant protein $[6,44]$. F protein also has heparin binding domains [45] and like G, can bind glycosaminoglycans [46,47]. Other possible receptors for RSV include the intercellular adhesion molecule-1 [48] and the CX3CR1 fracktalkine chemokine receptor $[3,17,49]$.

Virus-cell fusion occurs when the fusion peptide is inserted into the target cell membrane and the protein refolds into a hairpin structure assisted by HRA and HRB interactions to bring viral and target cell membranes into close proximity [39]. Viruses that lack $G(\Delta G)$ are capable of fusion and infection in vitro, although $\Delta \mathrm{G}$ viruses are highly attenuated in vivo [17]. Once virus and cell membranes are fused, internal viral components are released into the cytoplasm where RSV replication occurs. P and L proteins support RNA synthesis, both for the production of mRNAs and for the production of new negative-strand genomes ( 15 $\mathrm{kb}$ in size). During transcription and replication, the nucleoprotein supports and protects the genome and antigenome RNA. Perhaps shielding of RNA by the nucleoprotein helps avoid additional onset of host-defense mechanisms by TLR and other forms of signaling. Following de novo RNA and protein production, new virions assemble at the cell surface where they acquire an envelope membrane by budding and release from the mammalian cell $[3,17]$.

Expert Rev Vaccines. Author manuscript; available in PMC 2012 August 1. 


\section{Vaccine development $\&$ the immune system}

Harnessing the immune response by vaccination is the single most effective method for the control of human infectious disease. The strategies associated with most of today's licensed vaccines were developed decades or centuries ago. In recent years, highly sophisticated molecular techniques have simplified vaccine production and improved safety [50]. New techniques have also tempted researchers to test an extraordinary number of antigen manipulations and peptide reassortments [51], not all of which have been successful [52]. The application of fundamental immune concepts to the development of new vaccines is encouraged to ensure that products mimic pathogen structures and induce positive immune responses in the majority of humans [52]. This section reviews basic immune concepts that may impact vaccine efficacy, and may assist evaluation of old and new RSV vaccine candidates.

\section{The first vaccine success}

Edward Jenner was the first to formally demonstrate the benefit of vaccination in the 1790s, by vaccinating a young boy with material from cowpox lesions, and then deliberately exposing the boy to smallpox virus. The vaccine was successful in that protection against smallpox was observed [303]. It is now known that the cowpox virus was successful, because it activated durable B- and T-cell (lymphocyte) responses with cross-reactivity for smallpox virus [53-55]. Lessons from this event cannot be overstated as Jenner's work advanced the only vaccine to eradicate a human disease [56].

\section{Amplification of antigen-specific immune effectors}

Historical vaccine successes have shown that vaccines must mimic the proteins and peptides presented by a target pathogen so that the immune system can be pre-activated before pathogen exposure. The strength of the immune system lies in its vast array of B and T lymphocytes. Each lymphocyte carries a different receptor with a unique binding site determined by the cell's previous history of complex immunoglobulin or T-cell receptor (TCR) gene rearrangements. For any given pathogen, a fraction of lymphocytes will have 'specificity', in that their preformed receptor (antibody for B cells or TCR for T cells) will bind intricately to the foreign material (antigen, either native or processed) with a lock-andkey-type interaction. The 'specific' cells are those that are targeted by vaccination. Each person carries a different repertoire of lymphocytes reflecting their unique array of gene rearrangements. Despite differences among humans, the sheer quantity of lymphocytes in each individual ensures that he/she will respond to essentially any complex foreign pathogen in nature $[50,57]$.

Upon first pathogen exposure, specific lymphocyte receptors are triggered by their interactions with antigens, after which the respective parent cells divide to generate large numbers of identical daughter cells. For B cells, somatic mutation and selection can further improve antibody binding potentials [58]. A portion of B cells also mature to become plasma cells (also termed antibody-forming cells or antibody-secreting cells), which constitutively secrete antibodies. After priming, memory B cells and T cells can provide long-term surveillance of the blood, lymph, peripheral tissues and mucosal surfaces, in some cases for the lifetime of an animal [59-61].

Vaccines that successfully mimic their target pathogen in terms of processed and unprocessed antigens will prime the three classical subsets of immune effectors (B cells, $T$ helper cells and cytotoxic $\mathrm{T}$ lymphocytes) and may harness the greatest benefit from the immune system. If the match of vaccine and pathogen is not precise, the receptors on primed lymphocytes will provide limited benefit and may possibly cause harm. When a pathogen's 
antigens are well conserved in nature, a single-component vaccine can be successful. When a pathogen's antigens are diverse, cocktail vaccines are most effective, as each antigen in the cocktail can trigger a different subpopulation of specific lymphocytes $[62,63]$. To date, researchers have successfully mimicked pathogen structures by:

- Attenuating the pathogen (e.g., cold-adapted influenza virus vaccine)

- Killing the pathogen (e.g., killed polio virus vaccine)

- Identifying a related virus from another species (the Jennerian approach)

- Isolating membrane molecules from a pathogen's coat (e.g., hepatitis B virus vaccine)

\section{Mechanisms of antibody-mediated protection}

In a vaccinated individual, antibodies provide a powerful first line of adaptive immune defense. These preformed effectors naturally circulate through blood and lymph and bathe mucosal surfaces so that they may immediately bind pathogen without additional cell stimulation or antigen processing. Mechanisms of antibody-mediated protection [64-67] include, but are not limited to:

- Aggregation of pathogen;

- Direct inhibition of receptor-ligand interactions between pathogen and host target cell;

- Inhibition of membrane fusion;

- Inhibition of virions within the cytosol of an infected cell [64];

- Labeling of the pathogen for destruction by phagocytes (opsonization);

- Induction of complement-mediated kill;

- Induction of degranulation by mast cells or eosinophils;

- Labeling of virus-infected host cells for destruction by innate immune effectors such as natural killer cells (antibody-dependent cell-mediated cytotoxicity).

$\operatorname{IgA}$ is particularly well suited for the control of respiratory virus infections as this isotype frequently bathes the mucosal lining of the respiratory tract. With assistance from the polyIg receptor, IgA antibodies transcytose across epithelial cells to enter the lumen of the respiratory tract, and are tethered to the airway lining by secretory component [58]. IgG can also cross epithelial cells into the respiratory tract and, in the absence of $\operatorname{IgA}$, can protect against RSV disease $[68,69]$. Neutralizing antibody titers correlate well with protection against RSV disease in some, but not all cases. Humans with low serum antibody neutralization titers are often more likely to be hospitalized, whereas a titer of $>100$ associates with a better outcome [70,71]. In one cotton rat passive transfer study, the serum antibody titer necessary for protection against RSV lung infection was 380 units. To protect the upper respiratory tract from infection, a ten-times higher serum antibody titer was required [71-73].

\section{Mechanisms of CD4+ T-cell-mediated protection}

$\mathrm{CD}^{+} \mathrm{T}$ cells secrete cytokines, assist $\mathrm{B}$ - and T-cell activation/function, and interact with the innate immune system to control pathogen growth $[58,74,75]$. Except in rare situations (Tcell-independent responses) $\mathrm{CD}^{+} \mathrm{T}$ cells may be essential for the induction and durability of protective immunity. $\mathrm{CD}^{+} \mathrm{T}$ cells can also reduce virus load in the absence of their $\mathrm{CD} 8^{+} \mathrm{T}$ - and B-cell partners $[76,77] . \mathrm{CD}^{+} \mathrm{T}$ cells do not recognize free antigens, but 
recognize the antigen's peptides, processed by B cells or other antigen-presenting cells to associate with MHC class II antigens on the mammalian cell surface. Antigen processing for $\mathrm{CD} 4^{+} \mathrm{T}$-cell activation usually initiates when an antigen-antibody complex or particle is engulfed by a B cell or antigen is engulfed by another APC, after which proteins are fragmented in endosomes, bound into the peptide binding grooves of MHC class II molecules, and returned to the cell surface. Because humans have widely disparate MHC antigens, a pathogen's most immunogenic (immunodominant) peptides will differ from one individual to the next. Algorithms are in some cases useful to predict which peptide sequences will 'fit' into the peptide-binding groove of a particular MHC molecule. The context of a peptide within a viral protein will also influence its immunogenicity, because a peptide's position will determine its accessibility to the proteases and other enzymes necessary for protein fragmentation and peptide assembly with MHC [78,79]. Certain peptides also compete with one another for presentation; when taken into a new context, an otherwise weak peptide may claim immunodominance [80]. An additional factor that will influence immunogenicity is the similarity of peptide to 'self' proteins, because lymphocytes responsive to 'self' are usually eliminated or inactivated by tolerance mechanisms [81-85]. However another influence on immunogenicity is the precise repertoire of lymphocytes within each host, as not every individual carries a TCR that will bind a given peptide. In summation, a peptide that elicits a strong response in the context of a pathogen may not do so when placed in an artifactual context, and a peptide that elicits a strong response in one individual may not do so in another. This explains in part why the frequency of vaccine responsiveness in the human population can be disappointing when antigen scope is reduced and when peptide contexts are altered [52].

$\mathrm{CD} 4^{+} \mathrm{T}$-cell subpopulations have been the topic of much debate in the RSV vaccine community (see formalin-inactivated RSV vaccine discussion later). $\mathrm{CD}^{+} \mathrm{T}$ cells are subdivided into multiple subsets including Th1, Th2, Th17 and Tregs. Th1 responses typically associate with interleukins IL-2, IFN- $\gamma$ and IL-12 (the latter produced by macrophages and dendritic cells), and IgG antibody isotypes of various subclasses (e.g., $\operatorname{IgG} 2 \mathrm{a}$ in mice). Th2 populations more often associate with interleukins IL-4, IL-5, IL-6, IL-10 and IL-13, and antibody isotypes $\operatorname{IgM}, \operatorname{IgG}, \operatorname{IgE}$ and $\operatorname{IgA}[58,86-90]$. It should be noted that Th1 and Th2 patterns and profiles are not absolute or mutually exclusive. The appearance of one cytokine from a particular $\mathrm{CD} 4^{+} \mathrm{T}$-cell subset during an immune response does not ensure the appearance of all others [86]. Furthermore, there is no globally accepted standard measurement of Th1 and Th2 cells; one laboratory may measure IL-4 to quantify a Th2 response while another may measure IL-10 or IL-13. The quality and quantity of membrane markers used to define different T-cell subsets also vary among laboratories. Caution must therefore be taken to avoid the mistaken assignment of dissimilar cells to a single population.

Treg and Th17 cells, like other T-cell types, are defined in some cases by phenotype and in other cases by function. The Treg cell is typically $\mathrm{CD} 4{ }^{+} \mathrm{CD} 25^{+}$and FoxP3 $3^{+}$. These cells can downregulate immune responses using antigen-specific and nonspecific mechanisms [9195]. Unlike the Treg cell, the IL-17-producing Th17 cell is most often associated with inflammation [96,97]. Environmental factors influence the development and ratios of Tregs, Th17 cells and other T-cell subsets [98,99]. A fine balance of subsets is essential to ensure that the immune response is sufficiently robust to clear virus, but is not sufficiently robust to inflame tissues and block respiratory airways.

\section{Mechanisms of CD8+ T-cell-mediated protection}

$\mathrm{CD}^{+} \mathrm{T}$ cells can secrete cytokines and are best known for their CTL capacity. They act as a second line of defense when antibodies fail to clear viral particles before infection. Their kill 
of infected target cells inhibits the production of new virus particles. $\mathrm{CD} 8^{+} \mathrm{T}$ cells are classically induced after:

- Virus infection of a susceptible target

- Endogenous expression of viral proteins

- Fragmentation of proteins in proteasomes

- Transporter activated protein-mediated entry of peptides into the endoplasmic reticulum

- Association of peptides with MHC class I proteins

- Presentation of MHC-peptide complexes on the infected cell surface

$\mathrm{CD}^{+} \mathrm{T}$ cells can also be responsive to exogenous antigens after cross-presentation, but this mode of antigen processing is generally less efficient [100-102]. The preference of CD8 ${ }^{+} \mathrm{T}$ cells for peptides from endogenously expressed viral proteins ensures that uninfected cells will not often be killed.

The combined activities of antibodies, and $\mathrm{CD} 4^{+}$and $\mathrm{CD} 8^{+} \mathrm{T}$ cells present an impressive defense against infectious disease. The vaccine developer benefits in that he/she need not create an immune system, but must simply pre-activate the antigen-specific lymphocytes that naturally exist in the healthy human.

\section{In vitro \& in vivo models for RSV vaccine development}

There is currently no single globally accepted model for the study of RSV vaccines and no model in which RSV disease matches that of humans. Instead, a variety of different systems are used. Small animal models include the BALB/c mouse, the hamster [103] and the cotton rat (Stenopus hispidus) $[41,104,105]$. The mouse model is attractive owing to the plethora of associated reagents and the availability of congenic, mutant, transgenic and knock-out strains. Disadvantages are that high RSV doses are required for infection. The cotton rat is more susceptible to infection, but lacks a comparable reagent pool. Primate models include rhesus macaques [106], African green monkeys [107] and chimpanzees, but none are highly susceptible to RSV disease. When a cold-adapted RSV vaccine was proven safe in chimpanzees, it nonetheless caused lower respiratory tract infection when translated to a clinical study in seronegative children [5,108]. Apart from animal models, in vitro models are also used to mimic the respiratory tract [109-113]. Cultures can be varied in terms of cell origin, cell type and environment. For example, a 3D air-liquid interface model of pediatric bronchial epithelium has been established to compare cells/functions between asthmatic and nonasthmatic children [111]. Cultures share some characteristics with the respiratory tract, but lack the complexity of the whole animal including the natural defenses of innate and adaptive immunity. Each model can provide important information concerning vaccine potential, but has limitations in terms of predicting clinical trial outcome.

\section{RSV vaccine development}

Respiratory syncytial virus vaccine development has progressed for a half century, yielding an extraordinary number of vaccine candidates. Products include killed virus, purified RSV proteins, attenuated RSV, nanoparticles, virus-like particles (VLPs; particles that mimic native virus conformation but lack genetic material), virosomes (vesicular membranes carrying virus-derived proteins without nucleocapsids or genetic material), replicationcompetent vectors carrying RSV genes, and replication-deficient vectors carrying RSV genes. Molecular tools include DNA-based, viral-based and bacterial-based vectors, which may be expressed in tissue culture, plants or animal hosts. The RSV proteins that have been 
studied most often are F and G, because they each appear on the native RSV particle and are important targets for neutralizing antibodies and effector T cells. Of the two molecules, $\mathrm{F}$ is better conserved and is perhaps better suited to induce lymphocytes that cross-react with antigens from RSV A and B isolates.

Later, a number of strategies will be described. An attempt is made to mention old and new strategies, at least briefly, to indicate the breadth of research activity. Despite many decades of research, most vaccine candidates have been tested only preclinically or in RSV seropositive humans. For many of these, features of safety and efficacy in a seronegative human target population are presumed, but unknown.

\section{The formalin-treated RSV vaccine: an early disappointment}

In the 1960s, a formalin-inactivated RSV vaccine (FI-RSV) was combined with alum for intramuscular injection of babies. Unfortunately, the vaccine was not efficacious and enhanced disease when participants were subsequently exposed to RSV. Hospitalizations were far more prevalent in the vaccinated group than among controls and there were two fatalities attributed to the vaccine $[5,17,114-116]$.

Both small and large animal models have been used in attempts to recapitulate the immunopathology of the FI-RSV vaccine. Models have included mice, cotton rats and primates. These models are instructive, but are in some cases influenced by artifacts including impurities that may exist in a vaccine or challenge virus [304]. RSV-infected humans have also been studied extensively in attempts to dissect correlates of immunopathology. Again caution must be taken when interpreting results, as pathology is influenced by a complexity of factors including virus growth, target cell death, airway size, virus-associated signals to the immune system, and inflammation. Minor fluctuations in any of these parameters (e.g., a slightly higher virus load or a slightly smaller airway) may tip the balance between safety and morbidity.

One scenario that could explain the FI-RSV result of the 1960s is as follows: the formalin inactivation of RSV destroyed key antibody-neutralizing determinants on the virus. Therefore, the antibodies that were primed by FI-RSV were capable of antigen binding and precipitation, but they did not recognize neutralizing determinants on the native virus and did not act as a first line of defense to clear RSV [6,117-119]. CTL responses were also minimal owing to the inert nature of the vaccine. Given that these important lines of defense were lacking, there was a high antigen burden in the lung after RSV infection, and consequent recruitment of cells into the lower respiratory tract. Included among cells were RSV-specific T cells, eosinophils and neutrophils $[41,120]$. Inflammation ultimately obstructed small airways leading to morbidity in many vaccinees [121-123].

An additional suggestion to explain the 1960s result is that the formalin treatment of the vaccine altered surface antigens to block natural TLR-4 signaling by the RSV F protein, which further impeded the natural processes of virus-specific antibody development [124]. In support of the notion that TLR signaling impacts RSV infection and disease, it has been shown that TLR-4 knockout mice clear RSV less well than their wild-type counterparts $[41,125]$. In humans, TLR polymorphisms have been associated with disease severity in some, but not all studies [3,126-129].

Debates continue as to which cell type(s) was the most important instigator of disease. Contradictory results make absolute conclusions difficult and suggest that the outcome was influenced by a composite of events rather than a single cell type. In a BALB/c mouse model, high Th2/Th1 cell ratios (IL-4 and IL-10 production) have been associated with immunopathology [130-132]. T cells marked with V $\beta 14$ TCR and with specificity for RSV 
$\mathrm{G}$ were deemed responsible for immunopathology following some, but not all strategies of vaccination $[132,133]$. In a monkey model, disease was associated with IL-5 and IL-13, as well as neutrophils and eosinophils. These types of results have lead some investigators to suggest that RSV vaccines should induce negligible neutrophil, eosinophil and/or Th2 responses (or negligible T-cell responses of all types) $[3,5,6]$.

On the other hand, there is evidence that Th2 cells need not always promote immunopathology during RSV infection [134]. For example, in infants with severe RSV infections, disease is sometimes associated with a predominance of Th1-like responses or high Th1/Th2 ratios [41,135-138]. In cotton rats, vaccination with the original Lot $100 \mathrm{FI}-$ RSV vaccine (used in the failed clinical trials of the 1960s) [120], did not upregulate Th2 cytokines exclusively. Rather, the FI-RSV vaccine additionally upregulated the expression of chemokine genes and Th1-associated cytokine genes such as IL-2, IFN- $\gamma$ and IL-12p40 [41,139]. Furthermore, it has been shown that some RSV vaccines that induce Th2 responses do not show immune-enhanced disease after RSV infection [140], and that infants who are deficient in T-cell-mediated immune responses suffer worse outcomes following RSV infections than their normal counterparts [3,141]. Perhaps this is not surprising, as Th2 responses can associate with $\operatorname{IgA}$ antibody production, and $\operatorname{Ig} \mathrm{A}$ is a key isotype for protection of the respiratory tract's mucosal surface [58].

The FI-RSV vaccine outcome suggested that eosinophils might be associated with risk, but eosinophils can be beneficial in other scenarios [142]. For example, transfer of eosinophils to the lungs of RSV-infected mice has, in some cases, been shown to enhance clearance of RSV and inhibit hyper-reactivity in the airways [143].

There are multiple means by which immunopathology can be modulated in small animal models. Prestimulation of CTL responses in a mouse model was demonstrated to be advantageous $[5,144,145]$. Tregs could also downregulate immunopathological effects [146]. In a mouse model, the administration of anti-RSV G monoclonal antibody 1 day prior to RSV infection reduced inflammation and disease [147], highlighting the advantage of partnering potent B- and T-cell responses for virus control. Adjuvants can modify immunopathological events, as demonstrated by researchers who formulated FI-RSV with CpG oligodeoxynucleotide, a host defense peptide, and polyphosphazene [148]. In a separate study, monophosphoryl lipid adjuvant was administered with FI-RSV to cotton rats, after which there was a decrease in the cytokine storm associated with vaccine-enhanced disease. In that model, expression of both Th1 and selected Th2 (IL-4, IL-5, IL-13, but not IL-10) cytokine genes was reduced $[41,139]$. Antisense RNAs have additionally been used as a means to reduce immune-mediated lung pathology [149]. In one model, mice were initially infected with RSV at 1 week of age and were reinfected at 6 weeks of age, after which they exhibited immunopathology (a situation that is not necessarily comparable to that in humans). The administration of IL- $4 \mathrm{R} \alpha$ antisense oligonucleotides during the primary RSV infection enhanced the ratio of Th1/Th2 responses and inhibited pulmonary dysfunction.

Taken together, the results described earlier re-emphasize the complexities of vaccinemediated protection versus immunopathology. There are clearly numerous subtleties that impact the overall outcome of vaccination. One result of the FI-RSV clinical trial is that the development of subunit vaccines or killed vaccines for the pediatric arena is often discouraged $[3,5,6]$. These vaccines are at some disadvantage because booster(s) may be required to elicit sustained immune activity whereas replication-competent vectors can confer rapid immunity after a single inoculation [59-61]. Rapid induction of protective immunity is clearly desired for infants who are at immediate risk of RSV infection. An additional disadvantage of subunit or killed vaccines is that they do not promote endogenous 
antigen expression and therefore induce relatively low CTL activity (dependent on antigen cross-presentation as described earlier). Despite these limitations, subunit or killed vaccines also provide advantages. They benefit in that they can be administered by intramuscular injection and do not require cell transfection, transduction or infection in the host. Also, they have succeeded historically in preventing human disease (e.g., hepatitis B virus vaccine). These features suggest that new candidate vaccines of multiple modalities, if capable of inducing robust neutralizing B- and T-cell responses, deserve consideration. An unbiased evaluation of each new candidate vaccine based on overall outcome may help avoid the possible rejection of vaccines that are beneficial, or approval of vaccines that are not.

\section{RSV G-based protein vaccine, BBG2Na}

BBG2Na is a fragment of the RSV G protein (residues 130-230) fused to the albuminbinding domain of streptococcal protein G, produced in bacteria and often formulated in an alum-based adjuvant $[17,150,151]$. In small and large animals, BBG2Na has been shown to elicit an immune response [106,150,152,153]. Initial studies of BBG2Na in RSV seropositive humans were also promising [154], but clinical trials did not progress owing to rare unexpected development of purpura in some vaccinees [155,156]. Efforts are underway to reformulate RSV G protein fragments to improve upon durable immune responses while avoiding adverse events [157].

\section{Purified F protein}

There have been numerous attempts to formulate $\mathrm{F}$ protein vaccines with adjuvants or as a chimeric protein with RSV G [158-163]. Purified fusion protein (PFP) has been administered in alum to humans, both alone and in combination with infectious RSV vaccines [164]. PFP defines a series of candidate vaccines including PFP-3, an ionexchange-purified F protein from a cold-adapted temperature-sensitive isolate of RSV A2 with enhanced levels of F expression [165]. Generally, PFP vaccines were well tolerated in seropositive humans and were able to induce neutralizing antibody activities. Nonetheless, the impact of vaccines on lower respiratory tract infections with RSV was not high enough to encourage continued investigation in children, pregnant women or the elderly $[160,166-$ 168]. For example, when PFP-2 was administered to expectant mothers, the changes in neutralizing antibody activities in mother and infant were modest and RSV incidence in infants was not significantly altered [168]. Purified F proteins remain a topic of interest, with recent attention paid to the protein's postfusion structure [169].

\section{RSV F, G and/or M subunit vaccines}

Combinations of RSV F, G and M proteins have been clinically tested. In one case, a combination product was tested in the elderly ( $>65$ years age group) with or without alum. The best response was seen with a $100-\mu \mathrm{g}$ dose in the absence of alum. In this case, more than $50 \%$ of individuals experienced a greater than four-fold increase in neutralizing antibody titers $[6,170]$. The testing of subunit vaccines in seropositive young or elderly populations may possibly underestimate full vaccine potentials and complicate efficacy evaluations but, as stated earlier, there is reluctance in the field to advance subunit or killed vaccine candidates to the seronegative pediatric arena.

\section{Epitope scaffold vaccines}

As structure-function technological methods improve, it is now possible to examine the fine detail of immune interactions. For example, crystal structures are currently available of monoclonal RSV-specific neutralizing antibodies complexed with linear RSV peptide targets (e.g., structures exist for monoclonals motavizumab and 101F bound to peptide $[171,172])$. Information gained from studies of monoclonal B and T cells drives endeavors 
to isolate a select viral epitope(s) and integrate this artifactually with another protein sequence (carrier or scaffold [6,173-175]) to create vaccines. There are several challenges associated with the epitope-scaffold approach. First, the vaccine should mimic native RSV protein structures as necessary for the induction of cross-reactive RSV-specific antibodies (3D structures can influence antibody response patterns even when the target epitope is 'linear' [171,176-178]). Second, the processing of vaccine should yield MHC-peptide complexes matching those of RSV (T-cell receptor recognition of an MHC-peptide complex depends on protein fragmentation that can be affected by peptide flanking sequences and 3D context [78,179-182]). Third, the selected epitope(s) should induce a high-frequency of immune responses in humans with disparate B-/T-cell receptors and MHC haplotypes $[52,183]$.

\section{Nanoparticle vaccines}

Nanoparticle vaccines have been a current topic of considerable interest in the vaccine field. Biodegradable synthetic polymers (e.g., poly [p,L-lactic-co-glycolic acid]) can be used to create particles loaded with or chemically conjugated with antigens and adjuvants of choice $[184,185]$. Nanoparticle vaccines that incorporate antigenic components from RSV have been shown to stimulate mucosal and systemic immune responses in preclinical studies. These studies are in early stages of development [186].

\section{Propiolactone-treated RSV}

An inactivated RSV vaccine can be produced via treatment of virus with $\beta$-propiolactone, an alkylating agent that reacts with many nucleophilic reagents including nucleic acids. Combinations of inactivated RSV with CpG (a TLR-9 ligand) and MDP (a NOD2 receptor ligand), administered intranasally, induced mucosal IgA and serum $\operatorname{IgG}$, and were capable of protection against RSV in BALB/c mice [187]. As for other killed vaccines, the induction of robust $\mathrm{CD} 8^{+} \mathrm{T}$-cell responses may prove more difficult than with replication-competent vaccines, and boosters may be desirable. Owing to the FI-RSV vaccine experience, it remains to be seen if another killed vaccine approach will be advanced in the RSV field.

\section{Attenuated RSV}

Respiratory syncytial virus can be attenuated by multiple mechanisms including cold passage (cp), mutagenesis and reverse genetics. Previously, the serial cp of RSV has been partnered with chemical mutagenesis to select for attenuated temperature-sensitive (ts) mutants. Reverse genetics technology now lends to this process by facilitating rescue of viable RSV (or other viruses) bearing mutations of choice [188]. A first step in paramyxovirus reverse genetics methodology is to create a plasmid containing the entire viral genome, either with or without mutations. The plasmid is then transfected into a receptive host cell, usually in the presence of helper constructs that heighten viral protein expression. Infectious viral particles rescued from the host cell are expanded for further characterization. The reverse genetics strategy is a useful tool both for the study of mutation phenotypes and for the creation of desired vaccines.

A number of cold-passaged ts (cpts) viruses with mutations in $N, F, L$ and $M 2$ genes have been selected for use as attenuated vaccine candidates. Genome manipulations also include deletions of nonessential genes $N S 1, N S 2, S H$ or $M 2-2$, or manipulations of gene positions. Challenges are to identify an RSV derivative that is well tolerated in humans, is immunogenic, and replicates sufficiently to support scale-up of manufacturing [6].

One cpts vaccine, cpts248/404, was developed after CP and mutagenesis. Mutations were present in $N, F$ and $L$ genes and in the $M$ gene start signal, but the vaccine caused unacceptable nasal congestion in human infants $[5,189]$. Reverse genetics was then 
employed to rescue rA2cp248/404/1030 $\Delta$ SH with a mutated RSV genome devoid of the $S H$ gene and including a 1030 mutation in the $L$ gene. In early clinical trials, this vaccine was tested at two doses $\left(10^{4.3}\right.$ and $\left.10^{5.3} \mathrm{PFU}\right)$. Following vaccination of RSV seronegative children, peak vaccine titers were $10^{2.5} \mathrm{PFU}$ in nasal secretions. Only $44 \%$ of infants who were vaccinated twice with cA2cpts $248 / 404 / 1030 \Delta \mathrm{SH}$ at the $10^{5.3}$ dose had detectable antibody responses. Nonetheless, the first dose of vaccine may have impacted the second dose in that replication of the second vaccine dose was restricted $[5,190]$. This vaccine is now undergoing further testing in a Phase II clinical trial with seronegative infants [191]. Preclinical studies also continue to improve stability of the attenuated phenotype [192].

Another strategy has been to delete the NS2 gene in conjunction with the introduction of point mutations. Two vaccines, rA2cpts 248/404 NNS2 and rA2cpts530/1009 $\Delta$ NS2, were developed with this strategy, but in contrast to the cpts 248/404, these were not strongly immunogenic and have not been advanced [5]. Other live-attenuated RSVs include NS1 or M2-2-deletion mutants (RSV $\Delta$ M2-2 [191]). These have already been tested in nonhuman primates and may advance to human testing [193].

The MEDI-559 clinical trial conducted by MedImmune is currently testing an intranasal, recombinant, live-attenuated, ts RSV in a randomized, double-blind placebo-controlled study to evaluate viral shedding in healthy children from 1 to $<24$ months of age [6,305].

Merck is developing a live-attenuated vaccine using an RSV287 strain, initially isolated in the 1970s. The virus was subjected to serial in vitro passage in VERO cells yielding mutations in the $G, F$ and $L$ genes and 5 ' untranslated region. The vaccine induced an immune response in cotton rats. The response was weaker when cotton rats were administered anti-RSV immune sera to mimic maternal antibodies in infants [194].

One additional attenuated RSV vaccine candidate originated from the clinical RSV isolate 98-25147-X. A virus lacking the $G$ gene was produced by reverse genetics and was found to be nonreplicative in cotton rat lungs. After an intranasal vaccine inoculation, neutralizing antibodies were generated and protective immunity lasted for at least 10 weeks $[195,196]$.

In general, the attenuation of virus is considered an attractive approach and has been highly successful in other vaccine fields. The difficulty experienced over several decades has been to find a balanced RSV vaccine candidate that is sufficiently attenuated to avoid disease and is sufficiently robust to elicit a protective immune response in humans.

\section{RSV envelope-based virosomes}

A relatively new vaccine approach has been to present RSV viral envelopes in membranes without nucleocapsids or nucleic acids [197,198]. Tests with a RSV envelope-based virosome vaccine in vitro demonstrated NF- $\mathrm{KB}$ activation in macrophages, perhaps owing to TLR triggering by RSV F. When virosomes were reconstituted with RSV envelopes and incorporated the TLR-2 ligand P3CSK4, virus-neutralizing antibodies and IFN- $\gamma$-positive T cells were induced in mice. The RSV virosomes were protective against virus challenge in small animals and there were no symptoms of enhanced disease.

\section{Influenza-based virosomes carrying RSV F protein}

Another relatively new virosomal vaccine (PEV4) is influenza based and formulated to contain 10 or $50 \mu \mathrm{g}$ of RSV F protein. Microsomes were injected into BALB/c mice by subcutaneous inoculation twice or three times successively with 3-week intervals. Vaccinated animals generated an anti-RSV response associated with neutralizing activity. The vaccine prevented RSV replication upon challenge. Curiously, empty vectors were also 
associated with some nonspecific protection, a phenomenon that will be the topic of further study [199].

\section{Bovine RSV or bovine/human RSV chimeric viruses}

Bovine RSV vaccines are currently sold for use in cows, but the vaccine has not been protective against human RSV in chimpanzees, even when chimeric viruses were produced with human RSV F and G proteins substituted for bovine RSV F and G. Results were possibly due to the limited growth of bovine RSV in an unnatural host species $[5,200]$.

\section{Newcastle disease virus recombinants or virus-like particles}

A recombinant Newcastle disease virus (NDV) was created by reverse genetics to express the RSV F glycoprotein. BALB/c mice vaccinated with this recombinant were protected from RSV challenge, an outcome that correlated with RSV-specific CD8 ${ }^{+} \mathrm{T}$-cell activity [5,201]. In a separate study, NDV virus-like particles (VLPs) containing both RSV F and G proteins were prepared by combining NDV nucleocapsid and membrane proteins with chimeric proteins containing the ectodomains of RSV F and G proteins fused respectively to NDV F and HN protein transmembrane and cytoplasmic domains. A single immunization with the nonreplicating VLPs induced a relatively high $\mathrm{IgG} 2 \mathrm{a} / \mathrm{IgG} 1$ response in mice, and conferred protection against lung infection following an RSV challenge without immunopathology [202]. An additional VLP was developed using NP and M proteins of NDV and a chimeric protein containing the ectodomain of RSV G fused to transmembrane and cytoplamic domains of the NDV HN protein [203]. In this case no F protein was expressed. In a recent experiment, vaccination of mice with 10 or $40 \mu \mathrm{g}$ total VLP protein by intraperitoneal or intramuscular injection stimulated antibody responses to $G$ protein. One or two doses resulted in modest levels of neutralizing antibodies and the complete protection of mice from RSV replication in the lungs with no enhanced pathology.

Advantages of the VLP vaccine approach are that there are no concerns of virus spread or reversion, and for NDV, pre-existing immunity in humans is rare. NDV vaccines are currently used in veterinary medicine and VLP vaccines have advanced to clinical testing.

\section{Bovine/human PIV-3-recombinants}

Chimeric bovine/human parainfluenza virus type 3 (b/hPIV-3)-based vaccines have been constructed by reverse genetics to express RSV F $[3,103,107,204]$. One of these products, MEDI-534, is currently advancing through clinical trials. In African green monkeys, the vaccine was infectious. A dose of $2-3 \times 10^{5} \mathrm{PFU}$ given intranasally and intratracheally reached peak titers in upper respiratory tract samples of $>10^{5} \mathrm{PFU} / \mathrm{ml}$ and in lower respiratory tract samples of approximately $10^{7} \mathrm{PFU} / \mathrm{ml}$. Significant protection against subsequent RSV challenge was observed [107]. This vaccine has progressed through Phase I clinical trials in the 6-24-month age group. Three doses were tested $\left(10^{4}, 10^{5}\right.$ and $10^{6}$ tissue culture infectious doses 50 ). There was a statistically significant increase in rhinitis/ rhinorrhea in the group that received the $10^{4}$ vaccine dose compared with controls $(\mathrm{p}=$ 0.017), but not at higher vaccine doses, suggesting that the phenomenon may have been coincidental rather than indicative of vaccine-related disease. There was no evidence of enhanced disease following natural exposure to RSV in this study. At the highest vaccine dose, seroconversion to RSV was at the $67 \%$ level and seroconversion to PIV-3 was $100 \%$. A large international clinical trial in infants is now underway [205].

\section{Sendai virus-based recombinants}

An unmanipulated Sendai virus ( $\mathrm{SeV}$; a parainfluenza virus type I of mice) has been studied as a vaccine for human parainfluenza virus type I (hPIV-1), and a $\mathrm{SeV}$ recombinant virus 
carrying the RSV $F$ gene (SeVRSV) has been studied as a vaccine for RSV and hPIV-1. Despite ample opportunity for exposure between humans and mice, there has never been a confirmed clinical case of SeV-related disease in humans. This may be due in part to the unique sensitivity of $\mathrm{SeV}$ to human interferon-associated innate immune responses [206]. $\mathrm{SeV}$ has been shown to induce B- and T-cell responses in the upper respiratory tract (the point of entry for the target pathogen) and lower respiratory tract within 7-10 days of an intranasal inoculation in small animals. After vaccination, antibody-forming cells and $\mathrm{T}$ cells were maintained in diffuse nasal-associated lymphoid tissue for the animal's lifetime. Coincident with the immune response, $\mathrm{SeV}$ and recombinant $\mathrm{SeV}$ vaccines conferred rapid and durable protection against their target pathogens [59,60,207-211]. Furthermore, SeVRSV elicited neutralizing antibodies and protection against a variety of RSV A and B isolates. These results have encouraged the conduct of an ongoing Phase I clinical trial of $\mathrm{SeV}$ in adults and children, in which the vaccine has been well tolerated to date [212]. In African green monkey studies, immune activities against $\mathrm{SeV}$ or SeVRSV were generated without adverse events $[213,214]$. SeVRSV conferred complete protection against lower respiratory tract infection after RSV challenge. No clinically relevant adverse events were demonstrated after either vaccination or challenge in the large animal model. $\mathrm{SeV}$ and SeVRSV were more attenuated in the upper and lower respiratory tracts of primates than the b/hPIV-3-based RSV vaccine (described earlier), which is currently progressing through clinical trials. These results support plans to advance the SeVRSV vaccine product to the clinic [214].

\section{Modified Vaccinia Ankara recombinant vaccine}

Modified Vaccinia Ankara (MVA) has been tested as a vector for RSV gene delivery [215]. The strategy has demonstrated immunogenicity in chimpanzees, but the vaccine has not advanced to clinical trials. MVA gained considerable popularity as a smallpox vaccine when smallpox bioterrorism threats arose and when the safety profile of the standard smallpox vaccine (based on unmodified vaccinia virus) came into question [216-218]. Clinical trials with MVA-recombinant vaccines have been conducted in other vaccine fields [219,220], a situation that may prompt future studies with MVA-RSV recombinants. MVA is somewhat difficult to manufacture owing to its attenuated growth, but efforts have been made to perfect the process [221].

\section{DNA plasmid vaccines \& DNA in human papillomavirus pseudovirions}

DNA plasmid vaccines carrying a number of different RSV genes have been characterized in small and large animal models [222-226]. In addition, DNA immunizations have been administered following encapsidation of RSV nucleic acid sequences by the capsid proteins of human papillomavirus [227]. In one example, self-assembled pseudovirions carrying RSV $M$ and $M 2$ genes were produced. These were delivered intravaginally. Researchers found that immunization of mice with the pseudovirions induced M- and M2-specific CD8 ${ }^{+}$ T-cell and antibody responses similar to those induced by a 10,000-fold higher dose of naked DNA. In general, experiences in other vaccine fields have found that despite various formulations and modes of injection [228,229], DNA vaccines do not elicit robust and sustained immune responses when used in isolation. They nonetheless serve as useful priming tools in the context of heterologous vaccination regimens [230,231], and are most often advanced in this capacity.

\section{Adenovirus recombinants}

Adenovirus has been considered an attractive candidate vaccine backbone, in part because manufacturing is facilitated by robust virus growth in tissue culture [6]. Challenges to this approach include the natural exposure of humans to adenovirus 5 and consequent B- and Tcell immune responses, which can dampen vaccine efficacy [232,233]. Other adenovirus 
serotypes (e.g., 14, 26, 28 and 35), chimeric viruses, manipulated viruses or nonhuman primate adenoviruses provide additional options for vaccine design [234,235]. One recent study used a replication-deficient adenovirus ( $\mathrm{rAd}$ )-based codon-optimized vaccine expressing the soluble F1 fragment of F protein (amino acids 155-524) [236]. In mice, mucosal IgA responses were induced by one intranasal immunization with the vaccine. There was potent protection against subsequent RSV challenge, but neither serum antibodies nor $\mathrm{T}$ cells could be detected. When cholera toxin B subunit was used as an adjuvant with the vaccine, IgA responses were further enhanced.

\section{Semliki Forest virus recombinant}

Semliki Forest virus is an alphavirus, a small enveloped positive-strand RNA virus. Recombinant technology has been used to create both replication-competent vaccines and vaccines capable of only one round of infection [237,238]. In the latter case, recombinant RNA is packaged into virus particles by cotransfection with packaging-deficient helper RNAs. Resultant virus particles will infect cells and express high levels of recombinant gene products without expression of structural genes. Protein expression is supported by selfamplification of viral replicons and downregulation of host protein synthesis. Antiviral immunity has been elicited in BALB/c mice by a recombinant Semliki Forest virus particlebased vaccine encoding the RSV F and G proteins [239]. Intranasal immunization reduced lung RSV titers upon challenge without disease enhancement.

\section{Venezuelan equine encephalitis virus recombinant}

Another alphavirus-based vaccine is a Venezuelan equine encephalitis virus-based replicon particle that instructs expression of RSV F and/or G glycoproteins. Recombinant Venezuelan equine encephalitis vaccines elicit protective humoral and cellular responses in cotton rats and mice [240,241]. Most recently, a nonreplicating virus-based replicon particle carrying a RSV $F$ gene induced antibodies (including mucosal IgA) and CD8 ${ }^{+} \mathrm{T}$ cells in small animals, even in the context of passively transferred RSV antibodies. The vaccine controlled virus in the lungs and also reduced virus in the upper respiratory tract after RSV challenge. Future goals for the alphavirus-based vaccines are to demonstrate protection in a primate model and to establish methods for scale-up manufacturing [6,240].

\section{Recombinant bacteria}

Recombinant Bacillus Calmette-Guérin has been produced to express RSV genes. In mice, recombinant Bacillus Calmette-Guérin induced IFN- $\gamma$-producing Th1 cells [242]. In addition, adoptive transfer of both $\mathrm{CD}^{+}$and $\mathrm{CD}^{+} \mathrm{T}$ cells from vaccinated mice contributed to the clearance of RSV RNA, as measured by PCR, after RSV infection of host animals. Other bacteria used to deliver or express RSV genes include Salmonella [243] and Streptococcus [244]. One challenge associated with the expression of RSV genes by bacteria is that the antigens do not exhibit post-translational modifications typical of the mammalian host, and may fail to generate robust $\mathrm{CD} 8^{+} \mathrm{T}$-cell activities. Vaccines based on bacteria may also pose safety issues and problems with pre-existing immunity.

\section{Plant-based vaccines}

Recombinant technology also provides capacity to develop plant-based vaccines. For example, transgenic apples have recently been described that express the human RSV F protein [245]. Specifically, a gene driven by the CaMV 35S promoter was introduced into apple leaf tissues by Agrobacterium-mediated transformation. Two transgenic lines were developed in which the RSV $F$ gene was identified by PCR. Stable integration of the RSV $F$ transgene was confirmed and levels of F protein expression were as high as $20 \mu \mathrm{g}$ per gram of tissue. Plant-based vaccines are attractive in concept, but also face challenges concerning 
post-translational modifications atypical of mammalian cells, weak induction of $\mathrm{CD} 8^{+} \mathrm{T}$ cells and oral tolerance.

\section{Heterologous prime-boost vaccine regimens}

Prime-boost strategies are now being considered in which two different modes of vaccination are used in succession. Because there are many vaccine candidates and strategies, the number of potential prime-boost regimens is vast. In one study, rhesus monkeys were immunized with RSV F using a DNA recombinant vaccine to prime and a recombinant adenovirus to boost. DNA was administered by tattooing, intramuscular injection, intramuscular electroporation or intradermal electroporation [246]. RSVneutralizing antibodies and IFN- $\gamma$ ELISpot responses were identified, particularly when DNA was administered by intramuscular electroporation.

Another complex prime-boost strategy was described by researchers at Emory University using a BALB/c mouse model [247]. First, B cells were activated ex vivo and pulsed with an M2 (82-90) peptide. These cells were infused by intravenous inoculation. Mice were boosted three times with M2 (82-90) peptide, PolyI:C and costimulatory anti-CD40 antibody (TRIVAX). In first studies, researchers found an increase in CD8 ${ }^{+} \mathrm{T}$ cells responsive to the peptide and some protection in mice from RSV in the lungs postchallenge. The strategy in which cells are removed from an individual and reinfused after in vitro manipulations has been previously used in clinical research to treat cancer and HIV. Difficulties relate to cost, logistics, risks associated with in vitro manipulations and proof of efficacy [248-251]. There are also risks associated with antigen-nonspecific activation or killing of immune populations when antibodies specific for lymphocyte membrane proteins are used [252-254,306].

An additional prime-boost protocol has utilized an attenuated Salmonella typhimurium recombinant to deliver DNA followed by a recombinant rAd vector (somewhat similar to the DNA/adenovirus constructs described earlier) [255]. Specifically, researchers used an oral SL7207/pcDNA3.1/F prime and intranasal FGAd/F boost to generate immune responses to RSV in mice. The regimen generated stronger RSV-specific humoral and mucosal immune responses than the oral SL7207/pcDNA3.1/F regimen alone, and stronger cellular immune responses than the FGAd/F regimen alone. Upon RSV challenge, the prime-boost regimen showed increased efficacy based on histopathological analyses.

The strategy of prime-boost with heterologous carriers is attractive in theory in that any immune response elicited toward a first delivery vehicle during the primary immunization need not inhibit the 'take' of the booster immunization [231]. Nonetheless, the increased complexity of the vaccine may cause logistical difficulties at the manufacturing stage, a situation that could ultimately discourage advancement of products.

\section{Expert commentary \& five-year view}

The RSV field has gained a great deal of experience and knowledge upon which successful vaccine design may be based. The immune system comprises complex B- and T-cell populations that together combat invading pathogens. Vaccines that activate all three populations of RSV-specific lymphocytes (B cells, $\mathrm{CD}^{+}{ }^{+} \mathrm{T}$ cells and $\mathrm{CD} 8^{+} \mathrm{T}$ cells) might best harness the full strength of the immune system. When evaluating new vaccines, researchers must acknowledge the vast complexity of the immune system. The precise environment in which cells are found may influence final outcome, explaining the many discrepancies in RSV literature. As of yet, there is not sufficient scientific evidence to base acceptance or rejection of a vaccine candidate on a single cytokine or cellular measurement. 
Rather, comprehensive evaluations of outcome following vaccination may serve to select beneficial products and increase our understanding of protective immune correlates.

One of the difficulties of advancing any RSV vaccine candidate is that infants comprise an important target population, and the dire consequences of testing an ineffective RSV vaccine in infants has already been realized. When vaccines are tested in older persons who are already seropositive for RSV, data may be difficult to interpret and results may underestimate full vaccine potential. Vaccine opponents argue that infants usually recover from RSV infection (particularly in the USA) and that the risk of vaccine development is too high. There is also the logistical difficulty of coordinating RSV vaccination with the already-complex schedule of routine pediatric vaccinations.

Another concern relates to maternal antibodies which may impede vaccination in the newborn [256]. At birth, maternal antibody titers can be equal to, or more than titers in adults. However, as described previously, maternal antibodies fall substantially by 2 months after birth [14]. At this time, infants with the lowest antibody levels and greatest vulnerability to RSV infection are most likely to respond positively to an RSV vaccine.

Yet another concern among researchers is that the developing immune system may not respond to vaccination. Fortunately, the human immune system is more advanced at birth than that of some other mammalian species (e.g., mouse) and human infants are already known to respond positively to licensed pediatric vaccines [257,258].

RSV vaccines can be tested in the elderly, but this strategy also poses difficulties [259]. As with any adult RSV vaccine study, preexisting immune responses can hinder efficacy and complicate data interpretation [6]. Additionally, it may be difficult to assess the positive impact of a vaccine when unrelated abnormalities or infections mask the vaccine's protective effects $[19,167,260]$. For these reasons it is proposed that clinical vaccine trials in elderly populations must be designed with very large group sizes to distinguish between vaccine-related and vaccine-unrelated outcomes [261].

Despite the difficulties described earlier, a number of pharmaceutical companies (e.g., Novartis, Sanofi Pasteur, Novavax, GenVec and Crucell) and governments have recently asserted that the development of an RSV vaccine is of high priority. These and other initiatives toward preclinical and clinical development of novel and classical vaccine approaches lend optimism to the field. There are probably a number of vaccines that will ultimately prove safe and efficacious in infants and adults. One may gain much information from preclinical research using tissue culture and animal models. Cautious, steady advancement toward clinical research may then expedite vaccine discovery.

A successful RSV vaccine may well be developed within the next 5-10 years if preclinical and clinical trials progress efficiently and if candidate vaccines are tested in parallel. Clinical research may expedite vaccine discovery, illustrate true correlates of protection, and prevent the devastating disease caused by RSV worldwide.

\section{Key issues}

- Respiratory syncytial virus (RSV) is a catastrophic disease of children.

- The B cells and T cells of the immune system have an extraordinary capacity to ward off serious respiratory pathogens. To date, vaccines that activate only one of these populations (e.g., by preserving T-cell epitopes, but omitting or distorting neutralizing B-cell epitopes) have not been successful. Experiences in other vaccine fields encourage the development of vaccines that harness 
antibody activity as a first line of defense to destroy free pathogens, and harness $\mathrm{T}$ cells to recognize processed antigens and kill infected cells.

- Owing to the intricacies of antigen processing/presentation and immune repertoires, each individual may respond differently to a given pathogen. Furthermore, a peptide that is immunodominant in the pathogen's context need not be immunodominant when placed elsewhere. While advanced molecular techniques tempt antigen scrambling, past vaccine successes encourage preservation of antigenic structures and contexts to ensure the induction of pathogen-specific immune activities in the majority of humans.

- There are a multitude of strategies available to the field, several of which may yield a successful RSV vaccine. Most strategies have not yet been advanced to testing in the seronegative pediatric arena. Current enthusiasm for RSV vaccine development in academia and industry may prompt the implementation of new pediatric vaccine clinical trials and giant steps toward the prevention of RSV disease.

\section{Acknowledgments}

Acknowledgement is given to A Portner, KS Slobod, C Coleclough, C Russell, J Shenep and J DeVincenzo for useful discussions and advice. Acknowledgements are given to authors of previous RSV review articles and texts (Drs PL Collins, JE Crowe Jr, BS Graham, JCG Blanco, MS Boukhvalova, KA Shirey, GA Prince, SN Vogel, JH Schickli, F Dubovsky and RS Tang) and to Drs A Osterhaus, R de Swart and G van Bleek for organizing the 7th International Respiratory Syncytial Virus Symposium in 2010.

Work and writing were supported in part by NIH, NIAID grants P01-AI-054955, R01-AI088729, and R01AI78819, NCI grant P30-CA21765 and the American Lebanese Syrian Associated Charities. A patent application has been submitted describing Sendai virus as a vaccine vector.

\section{References}

Papers of special note have been highlighted as:

•• of considerable interest

1. Nair H, Nokes DJ, Gessner BD, et al. Global burden of acute lower respiratory infections due to respiratory syncytial virus in young children: a systematic review and meta-analysis. Lancet. 2010; 375:1545-1555. [PubMed: 20399493] •• Defines the global burden of respiratory syncytial virus (RSV) infection and disease.

2. Karron RA, Singleton RJ, Bulkow L, et al. Severe respiratory syncytial virus disease in Alaska native children. RSV Alaska Study Group. J. Infect. Dis. 1999; 180:41-49. [PubMed: 10353859]

3. Collins PL, Graham BS. Viral and host factors in human respiratory syncytial virus pathogenesis. J. Virol. 2008; 82:2040-2055. [PubMed: 17928346]

4. Hall CB, Weinberg GA, Iwane MK, et al. The burden of respiratory syncytial virus infection in young children. N. Engl. J. Med. 2009; 360:588-598. [PubMed: 19196675]

5. Schickli JH, Dubovsky F, Tang RS. Challenges in developing a pediatric RSV vaccine. Hum. Vaccin. 2009; 5:582-591. [PubMed: 19556888]

6. Graham BS. Biological challenges and technological opportunities for respiratory syncytial virus vaccine development. Immunol. Rev. 2011; 239:149-166. [PubMed: 21198670]

7. Shay DK, Holman RC, Roosevelt GE, Clarke MJ, Anderson LJ. Bronchiolitis-associated mortality and estimates of respiratory syncytial virus-associated deaths among US children, 197-1997. J. Infect. Dis. 2001; 183:16-22. [PubMed: 11076709]

8. Shay DK, Holman RC, Newman RD, et al. Bronchiolitis-associated hospitalizations among US children, 1980-1996. JAMA. 1999; 282:1440-1446. [PubMed: 10535434] 
9. Paramore LC, Mahadevia PJ, Piedra PA. Outpatient RSV lower respiratory infections among highrisk infants and other pediatric populations. Pediatr. Pulmonol. 2010; 45:578-584. [PubMed: 20503283]

10. Hall CB. Respiratory syncytial virus and parainfluenza virus. N. Engl. J. Med. 2001; 344:19171928. [PubMed: 11419430]

11. Bourgeois FT, Valim C, McAdam AJ, Mandl KD. Relative impact of influenza and respiratory syncytial virus in young children. Pediatrics. 2009; 124:e1072-e1080. [PubMed: 19933730]

12. Boyce TG, Mellen BG, Mitchel EF Jr, Wright PF, Griffin MR. Rates of hospitalization for respiratory syncytial virus infection among children in medicaid. J. Pediatr. 2000; 137:865-870. [PubMed: 11113845]

13. Piedra PA, Jewell AM, Cron SG, Atmar RL, Glezen WP. Correlates of immunity to respiratory syncytial virus (RSV) associated-hospitalization: establishment of minimum protective threshold levels of serum neutralizing antibodies. Vaccine. 2003; 21:3479-3482. [PubMed: 12850364]

14. Lewis DB, Wilson CB. Remington JS, Klein J, Baker C, Wilson C. Developmental immunology and role of host defenses in fetal and neonatal susceptibility to infection. Infectious Diseases of the Fetus and the Newborn Infant (6th Edition). 2005Philadelphia, PA, USASaunders:87-210. •• Provides an excellent review of the developing immune system in children.

15. Stensballe LG, Ravn H, Kristensen K, et al. Seasonal variation of maternally derived respiratory syncytial virus antibodies and association with infant hospitalizations for respiratory syncytial virus. J. Pediatr. 2009; 154:296-298. [PubMed: 19150677]

16. Glezen WP, Paredes A, Allison JE, Taber LH, Frank AL. Risk of respiratory syncytial virus infection for infants from low-income families in relationship to age, sex, ethnic group, and maternal antibody level. J. Pediatr. 1981; 98:708-715. [PubMed: 7229749]

17. Collins PL, Crowe JE. Knipe DM, Howley PM, Griffin DE, Lamb RA, Martin MA, Roizman B, Straus SE. Respiratory syncytial virus and metapneumovirus. Fields Virology. 2007PA, USALippincott Williams \& Wilkins:1601-1646. •• Provides an in-depth description of RSV virology.

18. El Saleeby CM, Somes GW, DeVincenzo JP, Gaur AH. Risk factors for severe respiratory syncytial virus disease in children with cancer: the importance of lymphopenia and young age. Pediatrics. 2008; 121:235-243. [PubMed: 18245413]

19. Falsey AR, Hennessey PA, Formica MA, Cox C, Walsh EE. Respiratory syncytial virus infection in elderly and high-risk adults. N. Engl. J. Med. 2005; 352:1749-1759. [PubMed: 15858184]

20. Falsey AR, Treanor JJ, Betts RF, Walsh EE. Viral respiratory infections in the institutionalized elderly: clinical and epidemiologic findings. J. Am. Geriatr. Soc. 1992; 40:115-119. [PubMed: 1740594]

21. Duncan CB, Walsh EE, Peterson DR, Lee FE, Falsey AR. Risk factors for respiratory failure associated with respiratory syncytial virus infection in adults. J. Infect. Dis. 2009; 200:1242-1246. [PubMed: 19758094]

22. King JC Jr, Burke AR, Clemens JD, et al. Respiratory syncytial virus illnesses in human immunodeficiency virus- and noninfected children. Pediatr. Infect. Dis. J. 1993; 12:733-739. [PubMed: 8414800]

23. Kim YJ, Boeckh M, Englund JA. Community respiratory virus infections in immunocompromised patients: hematopoietic stem cell and solid organ transplant recipients, and individuals with human immunodeficiency virus infection. Semin. Respir. Crit. Care Med. 2007; 28:222-242. [PubMed: 17458776]

24. King JC Jr. Community respiratory viruses in individuals with human immunodeficiency virus infection. Am. J. Med. 1997; 102:19-24. [PubMed: 10868138]

25. Simoes EA, Carbonell-Estrany X, Rieger $\mathrm{CH}$, et al. The effect of respiratory syncytial virus on subsequent recurrent wheezing in atopic and nonatopic children. J. Allergy Clin. Immunol. 2010; 126:256-262. [PubMed: 20624638]

26. Jackson DJ, Lemanske RF Jr. The role of respiratory virus infections in childhood asthma inception. Immunol. Allergy Clin. North. Am. 2010; 30:513-522. vi. [PubMed: 21029935]

27. Hall CB, Walsh EE, Long CE, Schnabel KC. Immunity to and frequency of reinfection with respiratory syncytial virus. J. Infect. Dis. 1991; 163:693-698. [PubMed: 2010624] 
28. DeVincenzo J, Lambkin-Williams R, Wilkinson T, et al. A randomized, double-blind, placebocontrolled study of an RNAi-based therapy directed against respiratory syncytial virus. Proc. Natl Acad. Sci. USA. 2010; 107:8800-8805. [PubMed: 20421463]

29. Ventre K, Randolph AG. Ribavirin for respiratory syncytial virus infection of the lower respiratory tract in infants and young children. Cochrane Database Syst. Rev. 2007; 1 CD000181.

30. Malley R, DeVincenzo J, Ramilo O, et al. Reduction of respiratory syncytial virus (RSV) in tracheal aspirates in intubated infants by use of humanized monoclonal antibody to RSV F protein. J. Infect. Dis. 1998; 178:1555-1561. [PubMed: 9815203]

31. Simoes EA, Groothuis JR, Carbonell-Estrany X, et al. Palivizumab prophylaxis, respiratory syncytial virus, and subsequent recurrent wheezing. J. Pediatr. 2007; 151:34-42. [PubMed: 17586188]

32. Butt ML, Symington A, Janes M, et al. The impact of prophylaxis on paediatric intensive care unit admissions for RSV infection: a retrospective, single-centre study. Eur. J. Pediatr. 2010; 170(7): 907-913. [PubMed: 21174120]

33. Gan SW, Ng L, Lin X, Gong X, Torres J. Structure and ion channel activity of the human respiratory syncytial virus (hRSV) small hydrophobic protein transmembrane domain. Protein Sci. 2008; 17:813-820. [PubMed: 18369195]

34. Roberts SR, Lichtenstein D, Ball LA, Wertz GW. The membrane-associated and secreted forms of the respiratory syncytial virus attachment glycoprotein $\mathrm{G}$ are synthesized from alternative initiation codons. J. Virol. 1994; 68:4538-4546. [PubMed: 8207828]

35. Bukreyev A, Yang L, Fricke J, et al. The secreted form of respiratory syncytial virus G glycoprotein helps the virus evade antibody-mediated restriction of replication by acting as an antigen decoy and through effects on Fc receptor-bearing leukocytes. J. Virol. 2008; 82:1219112204. [PubMed: 18842713]

36. Hendricks DA, McIntosh K, Patterson JL. Further characterization of the soluble form of the G glycoprotein of respiratory syncytial virus. J. Virol. 1988; 62:2228-2233. [PubMed: 3373568]

37. Sugrue RJ, Brown C, Brown G, Aitken J, McL RH. Furin cleavage of the respiratory syncytial virus fusion protein is not a requirement for its transport to the surface of virus-infected cells. J. Gen. Virol. 2001; 82:1375-1386. [PubMed: 11369882]

38. Dutch RE, Hagglund RN, Nagel MA, Paterson RG, Lamb RA. Paramyxovirus fusion (F) protein: a conformational change on cleavage activation. Virology. 2001; 281:138-150. [PubMed: 11222104]

39. Russell CJ, Luque LE. The structural basis of paramyxovirus invasion. Trends Microbiol. 2006; 14:243-246. [PubMed: 16678421]

40. Kurt-Jones EA, Popova L, Kwinn L, et al. Pattern recognition receptors TLR4 and CD14 mediate response to respiratory syncytial virus. Nat. Immunol. 2000; 1:398-401. [PubMed: 11062499]

41. Blanco JC, Boukhvalova MS, Shirey KA, Prince GA, Vogel SN. New insights for development of a safe and protective RSV vaccine. Hum. Vaccin. 2010; 6:482-492. [PubMed: 20671419]

42. Lo MS, Brazas RM, Holtzman MJ. Respiratory syncytial virus nonstructural proteins NS1 and NS2 mediate inhibition of Stat 2 expression and $\alpha / \beta$ interferon responsiveness. J. Virol. 2005; 79:93159319. [PubMed: 15994826]

43. Kolokoltsov AA, Deniger D, Fleming EH, et al. Small interfering RNA profiling reveals key role of clathrin-mediated endocytosis and early endosome formation for infection by respiratory syncytial virus. J. Virol. 2007; 81:7786-7800. [PubMed: 17494077]

44. Levine AM, Whitsett JA. Pulmonary collectins and innate host defense of the lung. Microbes Infect. 2001; 3:161-166. [PubMed: 11251302]

45. Feldman SA, Audet S, Beeler JA. The fusion glycoprotein of human respiratory syncytial virus facilitates virus attachment and infectivity via an interaction with cellular heparan sulfate. J. Virol. 2000; 74:6442-6447. [PubMed: 10864656]

46. Techaarpornkul S, Collins PL, Peeples ME. Respiratory syncytial virus with the fusion protein as its only viral glycoprotein is less dependent on cellular glycosaminoglycans for attachment than complete virus. Virology. 2002; 294:296-304. [PubMed: 12009871]

47. Hallak LK, Spillmann D, Collins PL, Peeples ME. Glycosaminoglycan sulfation requirements for respiratory syncytial virus infection. J. Virol. 2000; 74:10508-10513. [PubMed: 11044095] 
48. Behera AK, Matsuse H, Kumar M, et al. Blocking intercellular adhesion molecule-1 on human epithelial cells decreases respiratory syncytial virus infection. Biochem. Biophys. Res. Commun. 2001; 280:188-195. [PubMed: 11162498]

49. Tripp RA, Jones LP, Haynes LM, et al. CX3C chemokine mimicry by respiratory syncytial virus G glycoprotein. Nat. Immunol. 2001; 2:732-738. [PubMed: 11477410]

50. Zuckerman JN. Protective efficacy, immunotherapeutic potential, and safety of hepatitis B vaccines. J. Med. Virol. 2006; 78:169-177. [PubMed: 16372285]

51. Thomson SA, Jaramillo AB, Shoobridge M, et al. Development of a synthetic consensus sequence scrambled antigen HIV-1 vaccine designed for global use. Vaccine. 2005; 23:4647-4657. [PubMed: 15964105]

52. Cohen J. AIDS vaccines. HIV dodges one-two punch. Science. 2004; 305:1545-1547. [PubMed: 15361591]

53. Crotty S, Felgner P, Davies H, et al. Cutting edge: long-term B cell memory in humans after smallpox vaccination. J. Immunol. 2003; 171:4969-4973. [PubMed: 14607890]

54. Amanna IJ, Slifka MK, Crotty S. Immunity and immunological memory following smallpox vaccination. Immunol. Rev. 2006; 211:320-337. [PubMed: 16824139]

55. Slifka MK, Antia R, Whitmire JK, Ahmed R. Humoral immunity due to long-lived plasma cells. Immunity. 1998; 8:363-372. [PubMed: 9529153]

56. Fenner, F.; Henderson, DA.; Arita, I.; Jezek, Z.; Ladnyi, ID. Geneva, Switzerland: WHO; 1988. Smallpox and its Eradication.

57. Kapp JA, Pierce CW, Benacerraf B. Genetic control of immune responses in vitro. I. Development of primary and secondary plaque-forming cell responses to the random terpolymer 1-glutamic acid 60-61-alanine30-1-tyrosine10 (GAT) by mouse spleen cells in vitro. J. Exp. Med. 1973; 138:1107-1120. [PubMed: 4126766]

58. Murphy K, Travers P, Walport M. Janeway's Immunobiology. 2008NY, USAGarland Science •• Defines the basic mechanisms and complexities of innate and adaptive immune responses.

59. Rudraraju R, Surman S, Jones B, et al. Phenotypes and functions of persistent Sendai virus-induced antibody forming cells and $\mathrm{CD} 8^{+} \mathrm{T}$ cells in diffuse nasal-associated lymphoid tissue typify lymphocyte responses of the gut. Virology. 2011; 410:429-436. [PubMed: 21227475]

60. Sealy R, Jones BG, Surman SL, Hurwitz JL. Robust IgA and IgG-producing antibody forming cells in the diffuse-NALT and lungs of Sendai virus-vaccinated cotton rats associate with rapid protection against human parainfluenza virus-type 1. Vaccine. 2010; 28:6749-6756. [PubMed: 20682364]

61. Hyland L, Sangster M, Sealy R, Coleclough C. Respiratory virus infection of mice provokes a permanent humoral immune response. J. Virol. 1994; 68:6083-6086. [PubMed: 8057487]

62. Vesikari T, Wysocki J, Chevallier B, et al. Immunogenicity of the 10-valent pneumococcal nontypeable Haemophilus influenzae protein D conjugate vaccine (PHiD-CV) compared to the licensed 7vCRM vaccine. Pediatr. Infect. Dis. J. 2009; 28:S66-S76. [PubMed: 19325449]

63. Clark HF, Offit PA, Plotkin SA, Heaton PM. The new pentavalent rotavirus vaccine composed of bovine (strain WC3)-human rotavirus reassortants. Pediatr. Infect. Dis. J. 2006; 25:577-583. [PubMed: 16804425]

64. Mallery DL, McEwan WA, Bidgood SR, et al. Antibodies mediate intracellular immunity through tripartite motifcontaining 21 (TRIM21). Proc. Natl Acad. Sci. USA. 2010; 107:19985-19990. [PubMed: 21045130] •• Describes a new discovery that emphasizes the complex mechanisms by which antibodies inhibit virus replication.

65. Baumgarth N, Choi YS, Rothaeusler K, Yang Y, Herzenberg LA. B cell lineage contributions to antiviral host responses. Curr. Top. Microbiol. Immunol. 2008; 319:41-61. [PubMed: 18080414]

66. Forthal DN, Moog C. Fc receptor-mediated antiviral antibodies. Curr. Opin. HIV AIDS. 2009; 4:388-393. [PubMed: 20048702]

67. Neumann AU, Phillips S, Levine I, et al. Novel mechanism of antibodies to hepatitis B virus in blocking viral particle release from cells. Hepatology. 2010; 52:875-885. [PubMed: 20593455]

68. He W, Ladinsky MS, Huey-Tubman KE, et al. FcRn-mediated antibody transport across epithelial cells revealed by electron tomography. Nature. 2008; 455:542-546. [PubMed: 18818657] 
69. Null D Jr, Pollara B, Dennehy PH, et al. Safety and immunogenicity of palivizumab (Synagis) administered for two seasons. Pediatr. Infect. Dis. J. 2005; 24:1021-1023. [PubMed: 16282947]

70. Walsh EE, Falsey AR. Humoral and mucosal immunity in protection from natural respiratory syncytial virus infection in adults. J. Infect. Dis. 2004; 190:373-378. [PubMed: 15216475]

71. Prince GA, Horswood RL, Chanock RM. Quantitative aspects of passive immunity to respiratory syncytial virus infection in infant cotton rats. J. Virol. 1985; 55:517-520. [PubMed: 4020957]

72. Prince GA, Hemming VG, Horswood RL, Baron PA, Chanock RM. Effectiveness of topically administered neutralizing antibodies in experimental immunotherapy of respiratory syncytial virus infection in cotton rats. J. Virol. 1987; 61:1851-1854. [PubMed: 3553614]

73. Siber GR, Leombruno D, Leszczynski J, et al. Comparison of antibody concentrations and protective activity of respiratory syncytial virus immune globulin and conventional immune globulin. J. Infect. Dis. 1994; 169:1368-1373. [PubMed: 8195619]

74. Sun JC, Williams MA, Bevan MJ. CD4 ${ }^{+} \mathrm{T}$ cells are required for the maintenance, not programming, of memory $\mathrm{CD}^{+} \mathrm{T}$ cells after acute infection. Nat. Immunol. 2004; 5:927-933. [PubMed: 15300249]

75. Williams MA, Holmes BJ, Sun JC, Bevan MJ. Developing and maintaining protective CD8 ${ }^{+}$ memory T cells. Immunol. Rev. 2006; 211:146-153. [PubMed: 16824124]

76. Brown SA, Hurwitz JL, Zirkel A, et al. A recombinant Sendai virus is controlled by $\mathrm{CD}^{+}{ }^{+}$effector $\mathrm{T}$ cells responding to a secreted human immunodeficiency virus type 1 envelope glycoprotein. $\mathrm{J}$. Virol. 2007; 81:12535-12542. [PubMed: 17652379]

77. Surman SL, Brown SA, Jones BG, Woodland DL, Hurwitz JL. Clearance of HIV type 1 envelope recombinant Sendai virus depends on CD4 $\left({ }^{+}\right) \mathrm{T}$ cells and interferon- $\gamma$ but not B cells, CD8 $\left({ }^{+}\right) \mathrm{T}$ cells, or perforin. AIDS Res. Hum. Retroviruses. 2010; 26(7):783-793. [PubMed: 20623995]

78. Maric M, Arunachalam B, Phan UT, et al. Defective antigen processing in GILT-free mice. Science. 2001; 294:1361-1365. [PubMed: 11701933]

79. Nussbaum AK, Kuttler C, Hadeler KP, Rammensee HG, Schild H. PAProC: a prediction algorithm for proteasomal cleavages available on the WWW. Immunogenetics. 2001; 53:87-94. [PubMed: 11345595]

80. van der Most RG, Concepcion RJ, Oseroff C, et al. Uncovering subdominant cytotoxic Tlymphocyte responses in lymphocytic choriomeningitis virus-infected BALB/c mice. J. Virol. 1997; 71:5110-5114. [PubMed: 9188577]

81. Hale JS, Wubeshet M, Fink PJ. TCR revision generates functional CD4 ${ }^{+}$T cells. J. Immunol. 2010; 185:6528-6534. [PubMed: 20971922]

82. Vela JL, it-Azzouzene D, Duong BH, Ota T, Nemazee D. Rearrangement of mouse immunoglobulin $\kappa$ deleting element recombining sequence promotes immune tolerance and $\lambda \mathrm{B}$ cell production. Immunity. 2008; 28:161-170. [PubMed: 18261939]

83. Kappler JW, Roehm N, Marrack P. T cell tolerance by clonal elimination in the thymus. Cell. 1987; 49:273-280. [PubMed: 3494522]

84. Pullen AM, Marrack P, Kappler JW. The T-cell repertoire is heavily influenced by tolerance to polymorphic self-antigens. Nature. 1988; 335:796-801. [PubMed: 3263572]

85. Kappler JW, Staerz U, White J, Marrack PC. Self-tolerance eliminates T cells specific for Mlsmodified products of the major histocompatibility complex. Nature. 1988; 332:35-40. [PubMed: 3126396]

86. Kelso A. Th1 and Th2 subsets: paradigms lost? Immunol. Today. 1995; 16:374-379. [PubMed: 7546192]

87. Mosmann TR, Coffman RL. Th1 and Th2 cells: different patterns of lymphokine secretion lead to different functional properties. Annu. Rev. Immunol. 1989; 7:145-173. [PubMed: 2523712]

88. Mosmann TR, Cherwinski H, Bond MW, Giedlin MA, Coffman RL. Two types of murine helper T cell clone. I. Definition according to profiles of lymphokine activities and secreted proteins. J. Immunol. 1986; 136:2348-2357. [PubMed: 2419430]

89. Coffman R, Shrader B, Carty J, Mosmann T, Bond M. A mouse T cell product that preferentially enhances IgA production. J. Immunol. 1987; 139:3685-3690. [PubMed: 2960739] 
90. Lutzker S, Rothman P, Pollock R, Coffman R, Alt FW. Mitogen- and IL-4-regulated expression of germ-line Ig $\gamma$ 2b transcripts: evidence for directed heavy chain class switching. Cell. 1988; 53:177-184. [PubMed: 2834063]

91. Crother TR, Schroder NW, Karlin J, et al. Chlamydia pneumoniae infection induced allergic airway sensitization is controlled by regulatory T-cells and plasmacytoid dendritic cells. PLoS ONE. 2011; 6:e20784. [PubMed: 21695198]

92. Sakaguchi S, Yamaguchi T, Nomura T, Ono M. Regulatory T cells and immune tolerance. Cell. 2008; 133:775-787. [PubMed: 18510923]

93. Sakaguchi S, Sakaguchi N, Asano M, Itoh M, Toda M. Immunologic self-tolerance maintained by activated T cells expressing IL-2 receptor $\alpha$-chains (CD25). Breakdown of a single mechanism of self-tolerance causes various autoimmune diseases. J. Immunol. 1995; 155:1151-1164. [PubMed: 7636184]

94. Murphy TJ, Ni CN, Zang Y, Mannick JA, Lederer JA. CD $4^{+} \mathrm{CD} 25^{+}$regulatory T cells control innate immune reactivity after injury. J. Immunol. 2005; 174:2957-2963. [PubMed: 15728508]

95. Belkaid Y, Rouse BT. Natural regulatory T cells in infectious disease. Nat. Immunol. 2005; 6:353360. [PubMed: 15785761]

96. Ouyang W, Kolls JK, Zheng Y. The biological functions of T helper 17 cell effector cytokines in inflammation. Immunity. 2008; 28:454-467. [PubMed: 18400188]

97. Infante-Duarte C, Horton HF, Byrne MC, Kamradt T. Microbial lipopeptides induce the production of IL-17 in Th cells. J. Immunol. 2000; 165:6107-6115. [PubMed: 11086043]

98. Kryczek I, Wei S, Zou L, et al. Cutting edge: Th17 and regulatory T cell dynamics and the regulation by IL-2 in the tumor microenvironment. J. Immunol. 2007; 178:6730-6733. [PubMed: 17513719]

99. Zhu J, Paul WE. Peripheral CD4 ${ }^{+}$T-cell differentiation regulated by networks of cytokines and transcription factors. Immunol. Rev. 2010; 238:247-262. [PubMed: 20969597]

100. Heath WR, Belz GT, Behrens GM, et al. Cross-presentation, dendritic cell subsets, and the generation of immunity to cellular antigens. Immunol. Rev. 2004; 199:9-26. [PubMed: 15233723]

101. Zinkernagel RM. On cross-priming of MHC class I-specific CTL: rule or exception? Eur. J. Immunol. 2002; 32:2385-2392. [PubMed: 12207322]

102. Ackerman AL, Cresswell P. Cellular mechanisms governing cross-presentation of exogenous antigens. Nat. Immunol. 2004; 5:678-684. [PubMed: 15224093]

103. Schmidt AC, McAuliffe JM, Murphy BR, Collins PL. Recombinant bovine/human parainfluenza virus type 3 (B/HPIV3) expressing the respiratory syncytial virus (RSV) G and F proteins can be used to achieve simultaneous mucosal immunization against RSV and HPIV3. J. Virol. 2001; 75:4594-4603. [PubMed: 11312329]

104. Ottolini MG, Blanco JC, Eichelberger MC, et al. The cotton rat provides a useful small-animal model for the study of influenza virus pathogenesis. J. Gen. Virol. 2005; 86:2823-2830. [PubMed: 16186238]

105. Boukhvalova MS, Prince GA, Blanco JC. The cotton rat model of respiratory viral infections. Biologicals. 2009; 37:152-159. [PubMed: 19394861]

106. de WL, Power UF, Yuksel S, et al. Evaluation of BBG2Na in infant macaques: specific immune responses after vaccination and RSV challenge. Vaccine. 2004; 22:915-922. [PubMed: 15161068]

107. Tang RS, MacPhail M, Schickli JH, et al. Parainfluenza virus type 3 expressing the native or soluble fusion $(\mathrm{F})$ protein of respiratory syncytial virus (RSV) confers protection from RSV infection in African green monkeys. J. Virol. 2004; 78:11198-11207. [PubMed: 15452239]

108. Karron RA, Wright PF, Crowe JE Jr, et al. Evaluation of two live, cold-passaged, temperaturesensitive respiratory syncytial virus vaccines in chimpanzees and in human adults, infants, and children. J. Infect. Dis. 1997; 176:1428-1436. [PubMed: 9395351]

109. Wright PF, Ikizler MR, Gonzales RA, et al. Growth of respiratory syncytial virus in primary epithelial cells from the human respiratory tract. J. Virol. 2005; 79:8651-8654. [PubMed: 15956607] 
110. Guo-Parke, H.; Canning, P.; Douglas, I., et al. Comparative RSV cytopathogenesis in welldifferentiated paediatric airway epithelial cell models derived from the upper and lower respiratory tracts. Presented at: 7th International Respiratory Syncytial Virus Symposium; 12 December 2010; Rotterdam, The Netherlands. (Abstract p45)

111. Parker J, Sarlang S, Thavagnanam S, et al. A 3-D well-differentiated model of pediatric bronchial epithelium demonstrates unstimulated morphological differences between asthmatic and nonasthmatic cells. Pediatr. Res. 2010; 67:17-22. [PubMed: 19755931]

112. Herold S, Steinmueller M, von Wulffen W, et al. Lung epithelial apoptosis in influenza virus pneumonia: the role of macrophage-expressed TNF-related apoptosis-inducing ligand. J. Exp. Med. 2008; 205:3065-3077. [PubMed: 19064696]

113. Herold S, von WW, Steinmueller M, et al. Alveolar epithelial cells direct monocyte transepithelial migration upon influenza virus infection: impact of chemokines and adhesion molecules. J. Immunol. 2006; 177:1817-1824. [PubMed: 16849492]

114. Fulginiti VA, Eller JJ, Sieber OF, et al. Respiratory virus immunization I. A field trial of two inactivated respiratory virus vaccines an aqueous trivalent parainfluenza virus vaccine and an alum-precipitated respiratory syncytial virus vaccine. Am. J. Epidemiol. 1969; 89:435-448. [PubMed: 4305199]

115. Chin J, Magoffin RL, Shearer LA, Schieble JH, Lennette EH. Field evaluation of a respiratory syncytial virus vaccine and a trivalent parainfluenza virus vaccine in a pediatric population. Am. J. Epidemiol. 1969; 89:449-463. [PubMed: 4305200]

116. Kapikian AZ, Mitchell RH, Chanock RM, Shvedoff RA, Stewart CE. An epidemiologic study of altered clinical reactivity to respiratory syncytial (RS) virus infection in children previously vaccinated with an inactivated RS virus vaccine. Am. J. Epidemiol. 1969; 89:405-421. [PubMed: 4305197]

117. Polack FP, Teng MN, Collins PL, et al. A role for immune complexes in enhanced respiratory syncytial virus disease. J. Exp. Med. 2002; 196:859-865. [PubMed: 12235218]

118. Murphy BR, Walsh EE. Formalin-inactivated respiratory syncytial virus vaccine induces antibodies to the fusion glycoprotein that are deficient in fusion-inhibiting activity. J. Clin. Microbiol. 1988; 26:1595-1597. [PubMed: 2459154]

119. Murphy BR, Prince GA, Walsh EE, et al. Dissociation between serum neutralizing and glycoprotein antibody responses of infants and children who received inactivated respiratory syncytial virus vaccine. J. Clin. Microbiol. 1986; 24:197-202. [PubMed: 3755730]

120. Prince GA, Curtis SJ, Yim KC, Porter DD. Vaccine-enhanced respiratory syncytial virus disease in cotton rats following immunization with Lot 100 or a newly prepared reference vaccine. J. Gen. Virol. 2001; 82:2881-2888. [PubMed: 11714962]

121. Connors M, Giese NA, Kulkarni AB, et al. Enhanced pulmonary histopathology induced by respiratory syncytial virus (RSV) challenge of formalin-inactivated RSV-immunized BALB/c mice is abrogated by depletion of interleukin-4 (IL-4) and IL-10. J. Virol. 1994; 68:5321-5325. [PubMed: 8035532]

122. Kim EY, Battaile JT, Patel AC, et al. Persistent activation of an innate immune response translates respiratory viral infection into chronic lung disease. Nat. Med. 2008; 14:633-640. [PubMed: 18488036]

123. Kim HW, Canchola JG, Brandt CD, et al. Respiratory syncytial virus disease in infants despite prior administration of antigenic inactivated vaccine. Am. J. Epidemiol. 1969; 89:422-434. [PubMed: 4305198]

124. Shaw CA, Otten G, Wack A, et al. Antibody affinity maturation and respiratory syncytial virus disease. Nat. Med. 2009; 15:725-726. [PubMed: 19584854]

125. Haynes LM, Moore DD, Kurt-Jones EA, et al. Involvement of Toll-like receptor 4 in innate immunity to respiratory syncytial virus. J. Virol. 2001; 75:10730-10737. [PubMed: 11602714]

126. Awomoyi AA, Rallabhandi P, Pollin TI, et al. Association of TLR4 polymorphisms with symptomatic respiratory syncytial virus infection in high-risk infants and young children. J. Immunol. 2007; 179:3171-3177. [PubMed: 17709532] 
127. Paulus SC, Hirschfeld AF, Victor RE, et al. Common human Toll-like receptor 4 polymorphisms - role in susceptibility to respiratory syncytial virus infection and functional immunological relevance. Clin. Immunol. 2007; 123:252-257. [PubMed: 17449325]

128. Puthothu B, Forster J, Heinzmann A, Krueger M. TLR-4 and CD14 polymorphisms in respiratory syncytial virus associated disease. Dis. Markers. 2006; 22:303-308. [PubMed: 17264400]

129. Tal G, Mandelberg A, Dalal I, et al. Association between common Toll-like receptor 4 mutations and severe respiratory syncytial virus disease. J. Infect. Dis. 2004; 189:2057-2063. [PubMed: 15143473]

130. Graham BS, Bunton LA, Wright PF, Karzon DT. Role of T lymphocyte subsets in the pathogenesis of primary infection and rechallenge with respiratory syncytial virus in mice. $\mathrm{J}$. Clin. Invest. 1991; 88:1026-1033. [PubMed: 1909350]

131. Srikiatkhachorn A, Braciale TJ. Virus-specific $\mathrm{CD}^{+} \mathrm{T}$ lymphocytes downregulate $\mathrm{T}$ helper cell type 2 cytokine secretion and pulmonary eosinophilia during experimental murine respiratory syncytial virus infection. J. Exp. Med. 1997; 186:421-432. [PubMed: 9236194]

132. Varga SM, Wang X, Welsh RM, Braciale TJ. Immunopathology in RSV infection is mediated by a discrete oligoclonal subset of antigen-specific CD4 $\left(^{+}\right)$T cells. Immunity. 2001; 15:637-646. [PubMed: 11672545]

133. Johnson TR, Varga SM, Braciale TJ, Graham BS. V $\beta 14\left({ }^{+}\right)$T cells mediate the vaccine-enhanced disease induced by immunization with respiratory syncytial virus (RSV) G glycoprotein but not with formalin-inactivated RSV. J. Virol. 2004; 78:8753-8760. [PubMed: 15280483]

134. Welliver RC Sr. The immune response to respiratory syncytial virus infection: friend or foe? Clin. Rev. Allergy Immunol. 2008; 34:163-173. [PubMed: 17985249]

135. Mobbs KJ, Smyth RL, O’Hea U, et al. Cytokines in severe respiratory syncytial virus bronchiolitis. Pediatr. Pulmonol. 2002; 33:449-452. [PubMed: 12001278]

136. Garofalo RP, Patti J, Hintz KA, et al. Macrophage inflammatory protein-1 $\alpha$ (not T helper type 2 cytokines) is associated with severe forms of respiratory syncytial virus bronchiolitis. J. Infect. Dis. 2001; 184:393-399. [PubMed: 11471095]

137. Chen ZM, Mao JH, Du LZ, Tang YM. Association of cytokine responses with disease severity in infants with respiratory syncytial virus infection. Acta Paediatr. 2002; 91:914-922. [PubMed: 12412865]

138. Brandenburg AH, Kleinjan A, van Het LB, et al. Type 1-like immune response is found in children with respiratory syncytial virus infection regardless of clinical severity. J. Med. Virol. 2000; 62:267-277. [PubMed: 11002258]

139. Boukhvalova MS, Prince GA, Soroush L, et al. The TLR4 agonist, monophosphoryl lipid A, attenuates the cytokine storm associated with respiratory syncytial virus vaccine-enhanced disease. Vaccine. 2006; 24:5027-5035. [PubMed: 16675071]

140. Plotnicky H, Siegrist CA, Aubry JP, et al. Enhanced pulmonary immunopathology following neonatal priming with formalin-inactivated respiratory syncytial virus but not with the BBG2NA vaccine candidate. Vaccine. 2003; 21:2651-2660. [PubMed: 12744902]

141. Fishaut M, Tubergen D, McIntosh K. Cellular response to respiratory viruses with particular reference to children with disorders of cell-mediated immunity. J. Pediatr. 1980; 96:179-186. [PubMed: 6243354]

142. Rosenberg HF, Dyer KD, Domachowske JB. Respiratory viruses and eosinophils: exploring the connections. Antiviral Res. 2009; 83:1-9. [PubMed: 19375458]

143. Phipps S, Lam CE, Mahalingam S, et al. Eosinophils contribute to innate antiviral immunity and promote clearance of respiratory syncytial virus. Blood. 2007; 110:1578-1586. [PubMed: 17495130]

144. Olson MR, Varga SM. CD8 T cells inhibit respiratory syncytial virus (RSV) vaccine-enhanced disease. J. Immunol. 2007; 179:5415-5424. [PubMed: 17911628]

145. Stevens WW, Sun J, Castillo JP, Braciale TJ. Pulmonary eosinophilia is attenuated by early responding $\mathrm{CD} 8\left(^{+}\right)$memory T cells in a murine model of RSV vaccine-enhanced disease. Viral Immunol. 2009; 22:243-251. [PubMed: 19594395] 
146. Lee DC, Harker JA, Tregoning JS, et al. CD $25^{+}$natural regulatory T cells are critical in limiting innate and adaptive immunity and resolving disease following respiratory syncytial virus infection. J. Virol. 2010; 84:8790-8798. [PubMed: 20573822]

147. Radu GU, Caidi H, Miao C, et al. Prophylactic treatment with a G glycoprotein monoclonal antibody reduces pulmonary inflammation in respiratory syncytial virus (RSV)-challenged naive and formalin-inactivated RSV-immunized BALB/c mice. J. Virol. 2010; 84:9632-9636. [PubMed: 20592094]

148. van Drunen Littel-van den Hurk, S.; Latimer, L.; Brownlie, R., et al. Formulation of respiratory syncytial virus vaccine with a novel adjuvant platform induces a protective immune response in cotton rats. Presented at: 7th International Respiratory Syncytial Virus Symposium; 12 December 2010; Rotterdam, The Netherlands. (Abstract p151)

149. Ripple MJ, You D, Honnegowda S, et al. Immunomodulation with IL-4R alpha antisense oligonucleotide prevents respiratory syncytial virus-mediated pulmonary disease. J. Immunol. 2010; 185:4804-4811. [PubMed: 20861354]

150. Power UF, Plotnicky H, Blaecke A, Nguyen TN. The immunogenicity, protective efficacy and safety of BBG2Na, a subunit respiratory syncytial virus (RSV) vaccine candidate, against RSVB. Vaccine. 2003; 22:168-176. [PubMed: 14615143]

151. Goetsch L, Plotnicky-Gilquin H, Champion T, et al. Influence of administration dose and route on the immunogenicity and protective efficacy of BBG2Na, a recombinant respiratory syncytial virus subunit vaccine candidate. Vaccine. 2000; 18:2735-2742. [PubMed: 10781861]

152. Dagouassat N, Robillard V, Haeuw JF, et al. A novel bipolar mode of attachment to aluminiumcontaining adjuvants by BBG2Na, a recombinant subunit hRSV vaccine. Vaccine. 2001; 19:4143-4152. [PubMed: 11457539]

153. Power UF, Plotnicky-Gilquin H, Huss T, et al. Induction of protective immunity in rodents by vaccination with a prokaryotically expressed recombinant fusion protein containing a respiratory syncytial virus G protein fragment. Virology. 1997; 230:155-166. [PubMed: 9143271]

154. Power UF, Nguyen TN, Rietveld E, et al. Safety and immunogenicity of a novel recombinant subunit respiratory syncytial virus vaccine $(\mathrm{BBG} 2 \mathrm{Na})$ in healthy young adults. J. Infect. Dis. 2001; 184:1456-1460. [PubMed: 11709789]

155. Kneyber MC, Kimpen JL. Advances in respiratory syncytial virus vaccine development. Curr. Opin. Investig. Drugs. 2004; 5:163-170.

156. Durbin AP, Karron RA. Progress in the development of respiratory syncytial virus and parainfluenza virus vaccines. Clin. Infect. Dis. 2003; 37:1668-1677. [PubMed: 14689350]

157. Libon, C.; Nguyen, T.; Helffer, K., et al. Cross protective anti-RSV A and B immune responses induced after injection with G2Na alone versus combined G2Na/G2Nb in BALB/c mice and in cotton rats. Presented at: 7th International Respiratory Syncytial Virus Symposium; 12 December 2010; Rotterdam, The Netherlands. (Abstract p153)

158. Prince GA, Capiau C, Deschamps M, et al. Efficacy and safety studies of a recombinant chimeric respiratory syncytial virus FG glycoprotein vaccine in cotton rats. J. Virol. 2000; 74:1028710292. [PubMed: 11044072]

159. Groothuis JR, King SJ, Hogerman DA, Paradiso PR, Simoes EA. Safety and immunogenicity of a purified F protein respiratory syncytial virus (PFP-2) vaccine in seropositive children with bronchopulmonary dysplasia. J. Infect. Dis. 1998; 177:467-469. [PubMed: 9466539]

160. Simoes EA, Tan DH, Ohlsson A, Sales V, Wang EE. Respiratory syncytial virus vaccine: a systematic overview with emphasis on respiratory syncytial virus subunit vaccines. Vaccine. 2001; 20:954-960. [PubMed: 11738763]

161. Wathen MW, Kakuk TJ, Brideau RJ, et al. Vaccination of cotton rats with a chimeric FG glycoprotein of human respiratory syncytial virus induces minimal pulmonary pathology on challenge. J. Infect. Dis. 1991; 163:477-482. [PubMed: 1995720]

162. Oien NL, Brideau RJ, Walsh EE, Wathen MW. Induction of local and systemic immunity against human respiratory syncytial virus using a chimeric FG glycoprotein and cholera toxin B subunit. Vaccine. 1994; 12:731-735. [PubMed: 8091852] 
163. Brideau RJ, Walters RR, Stier MA, Wathen MW. Protection of cotton rats against human respiratory syncytial virus by vaccination with a novel chimeric FG glycoprotein. J. Gen. Virol. 1989; 70:2637-2644. [PubMed: 2677234]

164. Gonzalez IM, Karron RA, Eichelberger M, et al. Evaluation of the live attenuated cpts 248/404 RSV vaccine in combination with a subunit RSV vaccine (PFP-2) in healthy young and older adults. Vaccine. 2000; 18:1763-1772. [PubMed: 10699324]

165. Piedra PA, Cron SG, Jewell A, et al. Immunogenicity of a new purified fusion protein vaccine to respiratory syncytial virus: a multi-center trial in children with cystic fibrosis. Vaccine. 2003; 21:2448-2460. [PubMed: 12744878]

166. Piedra PA, Grace S, Jewell A, et al. Purified fusion protein vaccine protects against lower respiratory tract illness during respiratory syncytial virus season in children with cystic fibrosis. Pediatr. Infect. Dis. J. 1996; 15:23-31. [PubMed: 8684872]

167. Falsey AR, Walsh EE, Capellan J, et al. Comparison of the safety and immunogenicity of 2 respiratory syncytial virus (rsv) vaccines - nonadjuvanted vaccine or vaccine adjuvanted with alum - given concomitantly with influenza vaccine to high-risk elderly individuals. J. Infect. Dis. 2008; 198:1317-1326. [PubMed: 18855558]

168. Munoz FM, Piedra PA, Glezen WP. Safety and immunogenicity of respiratory syncytial virus purified fusion protein-2 vaccine in pregnant women. Vaccine. 2003; 21:3465-3467. [PubMed: 12850361]

169. Swanson KA, Settembre EC, Shaw CA, et al. Structural basis for immunization with postfusion respiratory syncytial virus fusion F glycoprotein (RSV F) to elicit high neutralizing antibody titers. Proc. Natl Acad. Sci. USA. 2011; 108:9619-9624. [PubMed: 21586636]

170. Langley JM, Sales V, McGeer A, et al. A dose-ranging study of a subunit Respiratory Syncytial Virus subtype A vaccine with and without aluminum phosphate adjuvantation in adults $>$ or $=65$ years of age. Vaccine. 2009; 27:5913-5919. [PubMed: 19651171]

171. McLellan JS, Chen M, Kim A, et al. Structural basis of respiratory syncytial virus neutralization by motavizumab. Nat. Struct. Mol. Biol. 2010; 17:248-250. [PubMed: 20098425]

172. McLellan JS, Chen M, Chang JS, et al. Structure of a major antigenic site on the respiratory syncytial virus fusion glycoprotein in complex with neutralizing antibody 101F. J. Virol. 2010; 84:12236-12244. [PubMed: 20881049]

173. Anderson R, Huang Y, Langley JM. Prospects for defined epitope vaccines for respiratory syncytial virus. Future Microbiol. 2010; 5(4):585-602. [PubMed: 20353300]

174. Ofek G, Guenaga FJ, Schief WR, et al. Elicitation of structure-specific antibodies by epitope scaffolds. Proc. Natl Acad. Sci. USA. 2010; 107:17880-17887. [PubMed: 20876137]

175. Liang X, Munshi S, Shendure J, et al. Epitope insertion into variable loops of HIV-1 gp120 as a potential means to improve immunogenicity of viral envelope protein. Vaccine. 1999; 17:28622872. [PubMed: 10438057]

176. D'Costa S, Slobod KS, Webster RG, White SW, Hurwitz JL. Structural features of HIV envelope defined by antibody escape mutant analysis. AIDS Res. Hum. Retroviruses. 2001; 17:1205-1209. [PubMed: 11522189]

177. Gerhard W, Yewdell J, Frankel ME, Webster R. Antigenic structure of influenza virus haemagglutinin defined by hybridoma antibodies. Nature. 1981; 290:713-717. [PubMed: 6163993]

178. Webster RG, Brown LE, Laver WG. Antigenic and biological characterization of influenza virus neuraminidase (N2) with monoclonal antibodies. Virology. 1984; 135:30-42. [PubMed: 6203218]

179. Sealy R, Chaka W, Surman S, et al. Target peptide sequence within infectious human immunodeficiency virus type 1 does not ensure envelope-specific T-helper cell reactivation: influences of cysteine protease and gamma interferon-induced thiol reductase activities. Clin. Vaccine Immunol. 2008; 15:713-719. [PubMed: 18235043]

180. Arnold PY, La Gruta NL, Miller T, et al. The majority of immunogenic epitopes generate $\mathrm{CD}^{+}{ }^{\mathrm{T}}$ cells that are dependent on MHC class II-bound peptide-flanking residues. J. Immunol. 2002; 169:739-749. [PubMed: 12097376] 
181. Moudgil KD, Sercarz EE, Grewal IS. Modulation of the immunogenicity of antigenic determinants by their flanking residues. Immunol. Today. 1998; 19:217-220. [PubMed: 9613039]

182. Surman S, Lockey TD, Slobod KS, et al. Localization of $\mathrm{CD}^{+} \mathrm{T}$ cell epitope hotspots to exposed strands of HIV envelope glycoprotein suggests structural influences on antigen processing. Proc. Natl Acad. Sci. USA. 2001; 98:4587-4592. [PubMed: 11287644]

183. McDevitt HO, Chinitz A. Genetic control of the antibody response: relationship between immune response and histocompatibility (H-2) type. Science. 1969; 163:1207-1208. [PubMed: 5765335]

184. Hamdy S, Haddadi A, Shayeganpour A, Samuel J, Lavasanifar A. Activation of antigen-specific T cell-responses by mannan-decorated PLGA nanoparticles. Pharm. Res. 2011; 28(9):22882301. [PubMed: 21560020]

185. Kasturi SP, Skountzou I, Albrecht RA, et al. Programming the magnitude and persistence of antibody responses with innate immunity. Nature. 2011; 470:543-547. [PubMed: 21350488]

186. Adair BM. Nanoparticle vaccines against respiratory viruses. Wiley Interdiscip. Rev. Nanomed. Nanobiotechnol. 2009; 1:405-414. [PubMed: 20049806]

187. De Haan, A.; Muhammad, S.; Wilschut, J. Mucosal immunization strategies for induction of respiratory syncytial virus-specific immunity; Presented at: 7th International Respiratory Syncytial Virus Symposium; 12 December 2010; Rotterdam, The Netherlands. (Abstract p154)

188. Nagai Y, Kato A. Paramyxovirus reverse genetics is coming of age. Microbiol. Immunol. 1999; 43:613-624. [PubMed: 10529101]

189. Wright PF, Karron RA, Belshe RB, et al. Evaluation of a live, cold-passaged, temperaturesensitive, respiratory syncytial virus vaccine candidate in infancy. J. Infect. Dis. 2000; 182:13311342. [PubMed: 11010838]

190. Karron RA, Wright PF, Belshe RB, et al. Identification of a recombinant live attenuated respiratory syncytial virus vaccine candidate that is highly attenuated in infants. J. Infect. Dis. 2005; 191:1093-1104. [PubMed: 15747245]

191. Buchholz, U.; Luongo, C.; Winter, C., et al. Live attenuated RSV and HMPV vaccines; Presented at: 7th Internationial Respiratory Syncytial Virus Symposium; 12 December 2010; Rotterdam, The Netherlands. (Abstact p135)

192. Luongo C, Yang L, Winter CC, et al. Codon stabilization analysis of the ' 248 ' temperature sensitive mutation for increased phenotypic stability of respiratory syncytial virus vaccine candidates. Vaccine. 2009; 27:5667-5676. [PubMed: 19646406]

193. Jin H, Cheng X, Traina-Dorge VL, et al. Evaluation of recombinant respiratory syncytial virus gene deletion mutants in African green monkeys for their potential as live attenuated vaccine candidates. Vaccine. 2003; 21:3647-3652. [PubMed: 12922094]

194. Liang, X. A live attenuated respiratory syncytial virus vaccine candidate produced by serial VERO cell passage; Presented at: 7th International Respiratory Syncytial Virus Symposium; 12 December 2010; Rotterdam, The Netherlands. (Abstract p145)

195. Widjojoatmodjo, MN.; Boes, J.; van Remmerden, Y., et al. A highly attenuated recombinant human RSV lacking the $\mathrm{G}$ protein confers long time protection against RSV infection in cotton rats; Presented at: 7th International Respiratory Syncytial Virus Symposium; 12 December 2010; Rotterdam, The Netherlands. (Abstract p149)

196. Widjojoatmodjo MN, Boes J, van BM, et al. A highly attenuated recombinant human respiratory syncytial virus lacking the $\mathrm{G}$ protein induces long-lasting protection in cotton rats. Virol. J. 2010; 7:114. [PubMed: 20525213]

197. Kamphuis, T.; Stegmann, T.; Merijerhof, T.; De Haan, A.; Wilschut, J. A virosomal respiratory syncytial virus vaccine with intrinsic adjuvant properties; Presented at: 7th International Respiratory Syncytial Virus Symposium; 12 December 2010; Rotterdam, The Netherlands. (Abstract p137)

198. Stegmann T, Kamphuis T, Meijerhof T, et al. Lipopeptide-adjuvanted respiratory syncytial virus virosomes: a safe and immunogenic non-replicating vaccine formulation. Vaccine. 2010; 28:5543-5550. [PubMed: 20600502]

199. Openshaw, P.; Sawant, D.; Olszewska, W., et al. PEV4: a novel virosomal vaccine that induces strong neutralizing antibody and protects mice against RSV infection; Presented at: 7th 
International Respiratory Syncytial Virus Symposium; 12 December 2010; Rotterdam, The Netherlands. (Abstract p148)

200. Buchholz UJ, Granzow H, Schuldt K, et al. Chimeric bovine respiratory syncytial virus with glycoprotein gene substitutions from human respiratory syncytial virus (HRSV): effects on host range and evaluation as a live-attenuated HRSV vaccine. J. Virol. 2000; 74:1187-1199.

[PubMed: 10627529]

201. Martinez-Sobrido L, Gitiban N, Fernandez-Sesma A, et al. Protection against respiratory syncytial virus by a recombinant Newcastle disease virus vector. J. Virol. 2006; 80:1130-1139. [PubMed: 16414990]

202. McGinnes LW, Gravel KA, Finberg RW, et al. Assembly and immunological properties of Newcastle disease virus-like particles containing the respiratory syncytial virus $F$ and $G$ proteins. J. Virol. 2011; 85:366-377. [PubMed: 20980510]

203. Murawski MR, McGinnes LW, Finberg RW, et al. Newcastle disease virus-like particles containing respiratory syncytial virus $\mathrm{G}$ protein induced protection in BALB/c mice, with no evidence of immunopathology. J. Virol. 2010; 84:1110-1123. [PubMed: 19889768]

204. Tang RS, Spaete RR, Thompson MW, et al. Development of a PIV-vectored RSV vaccine: preclinical evaluation of safety, toxicity, and enhanced disease and initial clinical testing in healthy adults. Vaccine. 2008; 26:6373-6382. [PubMed: 18822334]

205. Bernstein, D.; Malkin, E.; Charenkavanich, S.; Dubovsky, F. Safety profile, immunogenicity, and viral shedding of MEDI-534, a live, attenuated respiratory syncytial virus (RSV) and parainfluenza virus type 3 (PIV3) vaccine in RSV/PIV3 seronegative children; Presented at: 7th International Respiratory Syncytial Virus Symposium; 12 December 2010; Rotterdam, The Netherlands. (Abstract p139)

206. Bousse T, Chambers RL, Scroggs RA, Portner A, Takimoto T. Human parainfluenza virus type 1 but not Sendai virus replicates in human respiratory cells despite IFN treatment. Virus Res. 2006; 121:23-32. [PubMed: 16677733]

207. Jones B, Zhan X, Mishin V, et al. Human PIV-2 recombinant Sendai virus (rSeV) elicits durable immunity and combines with two additional rSeVs to protect against hPIV-1, hPIV-2, hPIV-3, and RSV. Vaccine. 2009; 27:1848-1857. [PubMed: 19200447]

208. Takimoto T, Hurwitz JL, Zhan X, et al. Recombinant Sendai virus as a novel vaccine candidate for respiratory syncytial virus. Viral Immunol. 2005; 18:255-266. [PubMed: 16035938]

209. Zhan X, Hurwitz JL, Krishnamurthy S, et al. Respiratory syncytial virus (RSV) fusion protein expressed by recombinant Sendai virus elicits B-cell and T-cell responses in cotton rats and confers protection against RSV subtypes A and B. Vaccine. 2007; 25:8782-8793. [PubMed: 18037543]

210. Zhan X, Slobod KS, Krishnamurthy S, et al. Sendai virus recombinant vaccine expressing hPIV-3 $\mathrm{HN}$ or F elicits protective immunity and combines with a second recombinant to prevent hPIV-1, hPIV-3 and RSV infections. Vaccine. 2008; 26:3480-3488. [PubMed: 18499307]

211. Takimoto T, Hurwitz JL, Coleclough C, et al. Recombinant Sendai virus expressing the G glycoprotein of respiratory syncytial virus (RSV) elicits immune protection against RSV. J. Virol. 2004; 78:6043-6047. [PubMed: 15141002]

212. Slobod KS, Shenep JL, Lujan-Zilbermann J, et al. Safety and immunogenicity of intranasal murine parainfluenza virus type 1 (Sendai virus) in healthy human adults. Vaccine. 2004; 22:3182-3186. [PubMed: 15297072]

213. Hurwitz JL, Soike KF, Sangster MY, et al. Intranasal Sendai virus vaccine protects African green monkeys from infection with human parainfluenza virus-type one. Vaccine. 1997; 15:533-540. [PubMed: 9160521]

214. Hurwitz, JL.; Shenep, JL.; Portner, A. Advancement of a Sendai virus-based RSV vaccine; Presented at: 7th International Respiratory Syncytial Virus Symposium; 12 December 2010; Rotterdam, The Netherlands. (Abstract p136)

215. Collins PL, Purcell RH, London WT, et al. Evaluation in chimpanzees of vaccinia virus recombinants that express the surface glycoproteins of human respiratory syncytial virus. Vaccine. 1990; 8:164-168. [PubMed: 2336876] 
216. Cono J, Casey CG, Bell DM. Smallpox vaccination and adverse reactions. Guidance for clinicians. MMWR Recomm. Rep. 2003; 52:1-28. [PubMed: 12617510]

217. Grabenstein JD, Winkenwerder W Jr. US military smallpox vaccination program experience. JAMA. 2003; 289:3278-3282. [PubMed: 12824209]

218. Sano J, Chaitman BR, Swindle J, Frey SE. Electrocardiography screening for cardiotoxicity after modified Vaccinia Ankara vaccination. Am. J. Med. 2009; 122:79-84. [PubMed: 19114175]

219. Gudmundsdotter L, Nilsson C, Brave A, et al. Recombinant modified Vaccinia Ankara (MVA) effectively boosts DNA-primed HIV-specific immune responses in humans despite pre-existing vaccinia immunity. Vaccine. 2009; 27:4468-4474. [PubMed: 19450644]

220. Hawkridge T, Scriba TJ, Gelderbloem S, et al. Safety and immunogenicity of a new tuberculosis vaccine, MVA85A, in healthy adults in South Africa. J. Infect. Dis. 2008; 198:544-552. [PubMed: 18582195]

221. Jordan I, Northoff S, Thiele M, et al. A chemically defined production process for highly attenuated poxviruses. Biologicals. 2011; 39:50-58. [PubMed: 21237672]

222. Li X, Sambhara S, Li CX, et al. Plasmid DNA encoding the respiratory syncytial virus G protein is a promising vaccine candidate. Virology. 2000; 269:54-65. [PubMed: 10725198]

223. Bembridge GP, Rodriguez N, Garcia-Beato R, et al. DNA encoding the attachment (G) or fusion (F) protein of respiratory syncytial virus induces protection in the absence of pulmonary inflammation. J. Gen. Virol. 2000; 81:2519-2523. [PubMed: 10993942]

224. Park EK, Soh BY, Jang YS, Park JH, Chung GH. Immune induction and modulation in mice following immunization with DNA encoding F protein of respiratory syncytial virus. Mol. Cells. 2001; 12:50-56. [PubMed: 11561730]

225. Vaughan K, Rhodes GH, Gershwin LJ. DNA immunization against respiratory syncytial virus (RSV) in infant rhesus monkeys. Vaccine. 2005; 23:2928-2942. [PubMed: 15780742]

226. Wu H, Dennis VA, Pillai SR, Singh SR. RSV fusion (F) protein DNA vaccine provides partial protection against viral infection. Virus Res. 2009; 145:39-47. [PubMed: 19540885]

227. Graham BS, Kines RC, Corbett KS, et al. Mucosal delivery of human papillomavirus pseudovirus-encapsidated plasmids improves the potency of DNA vaccination. Mucosal Immunol. 2010; 3:475-486. [PubMed: 20555315]

228. Lodmell DL, Ray NB, Ewalt LC. Gene gun particle-mediated vaccination with plasmid DNA confers protective immunity against rabies virus infection. Vaccine. 1998; 16:115-118. [PubMed: 9607018]

229. Torres CA, Iwasaki A, Barber BH, Robinson HL. Differential dependence on target site tissue for gene gun and intramuscular DNA immunizations. J. Immunol. 1997; 158:4529-4532. [PubMed: 9144463]

230. Richmond JFL, Mustafa F, Lu S, et al. Screening of HIV-1 Env glycoproteins for the ability to raise neutralizing antibody using DNA immunization and recombinant vaccinia virus boosting. Virology. 1997; 230:265-274. [PubMed: 9143282]

231. Brown SA, Surman SL, Sealy R, et al. Heterologous prime-boost HIV-1 vaccination regimens in pre-clinical and clinical trials. Viruses. 2010; 2:435-467. [PubMed: 20407589]

232. Abbink P, Lemckert AA, Ewald BA, et al. Comparative seroprevalence and immunogenicity of six rare serotype recombinant adenovirus vaccine vectors from subgroups B and D. J. Virol. 2007; 81:4654-4663. [PubMed: 17329340]

233. Thorner AR, Vogels R, Kaspers J, et al. Age dependence of adenovirus-specific neutralizing antibody titers in individuals from sub-Saharan Africa. J. Clin. Microbiol. 2006; 44:3781-3783. [PubMed: 17021110]

234. Roberts DM, Nanda A, Havenga MJ, et al. Hexon-chimaeric adenovirus serotype 5 vectors circumvent pre-existing anti-vector immunity. Nature. 2006; 441:239-243. [PubMed: 16625206]

235. Xiang Z, Gao G, Reyes-Sandoval A, et al. Novel, chimpanzee serotype 68-based adenoviral vaccine carrier for induction of antibodies to a transgene product. J. Virol. 2002; 76:2667-2675. [PubMed: 11861833]

236. Kim S, Jang JE, Yu JR, Chang J. Single mucosal immunization of recombinant adenovirus-based vaccine expressing F1 protein fragment induces protective mucosal immunity against respiratory syncytial virus infection. Vaccine. 2010; 28:3801-3808. [PubMed: 20362203] 
237. Liljestrom P, Garoff H. A new generation of animal cell expression vectors based on the Semliki Forest virus replicon. Biotechnology (NY). 1991; 9:1356-1361.

238. Riezebos-Brilman A, de MA, Bungener L, et al. Recombinant alphaviruses as vectors for antitumour and anti-microbial immunotherapy. J. Clin. Virol. 2006; 35:233-243. [PubMed: 16448844]

239. Chen M, Hu KF, Rozell B, et al. Vaccination with recombinant alphavirus or immune-stimulating complex antigen against respiratory syncytial virus. J. Immunol. 2002; 169:3208-3216.

[PubMed: 12218139]

240. Crowe, J.; Mok, H.; Hedgecock, J.; Shepherd, B.; Johnston, R. Alphavirus-based respiratory syncytial virus vaccine induces protection mediated by both humoral and cellular responses, even in the presence of passively-acquired antibodies; Presented at: 7th International Respiratory Syncytial Virus Symposium; 12 December 2010; Rotterdam, The Netherlands. (Abstract p142)

241. Mok H, Lee S, Utley TJ, et al. Venezuelan equine encephalitis virus replicon particles encoding respiratory syncytial virus surface glycoproteins induce protective mucosal responses in mice and cotton rats. J. Virol. 2007; 81:13710-13722. [PubMed: 17928349]

242. Cautivo KM, Bueno SM, Cortes CM, et al. Efficient lung recruitment of respiratory syncytial virus-specific Th1 cells induced by recombinant bacillus Calmette-Guerin promotes virus clearance and protects from infection. J. Immunol. 2010; 185:7633-7645. [PubMed: 21084664]

243. Xie C, He JS, Zhang M, et al. Oral respiratory syncytial virus (RSV) DNA vaccine expressing RSV F protein delivered by attenuated Salmonella typhimurium. Hum. Gene Ther. 2007; 18:746752. [PubMed: 17696764]

244. Falcone V, Mihm D, Neumann-Haefelin D, et al. Systemic and mucosal immunity to respiratory syncytial virus induced by recombinant Streptococcus gordonii surface-displaying a domain of viral glycoprotein G. FEMS Immunol. Med. Microbiol. 2006; 48:116-122. [PubMed: 16965359]

245. Lau JM, Korban SS. Transgenic apple expressing an antigenic protein of the human respiratory syncytial virus. J. Plant Physiol. 2010; 167:920-927. [PubMed: 20307914]

246. Grunwald, T.; Tenbusch, M.; Hannaman, D., et al. Immunogenicity of different delivery strategies of RSV DNA vaccines in rhesus monkeys; Presented at: 7th International Respiratory Syncytial Virus Symposium; 12 December 2010; Rotterdam, The Netherlands. (Abstract p143)

247. Lee, S.; Currier, M.; Stokes, K.; Celis, E.; Moore, M. B cell and peptide based immunotherapy vaccine for respiratory cyncytial virus infection; Presented at: 7th International Respiratory Syncytial Virus Symposium; 12 December 2010; Rotterdam, The Netherlands. (Abstract p150)

248. Rosenberg SA, Spiess P, Lafreniere R. A new approach to the adoptive immunotherapy of cancer with tumor-infiltrating lymphocytes. Science. 1986; 233:1318-1321. [PubMed: 3489291]

249. Goff SL, Smith FO, Klapper JA, et al. Tumor infiltrating lymphocyte therapy for metastatic melanoma: analysis of tumors resected for TIL. J. Immunother. 2010; 33:840-847. [PubMed: 20842052]

250. Picard O, Giral P, Defer MC, et al. AIDS vaccine therapy: Phase I trial. Lancet. 1990; 336:179. [PubMed: 1973493]

251. Picard O, Lebas J, Imbert JC, Bigel P, Zagury D. Complication of intramuscular/subcutaneous immune therapy in severely immune-compromised individuals. J. Acquir. Immune Defic. Syndr. 1991; 4:641-643. [PubMed: 1673716]

252. Boyman O, Krieg C, Letourneau S, Pantaleo G. Insight into mechanism of IL-2-induced toxicity provides rationale for improved treatment strategy using IL-2/mAb complexes. J. Immunol. 2009; 182:38.8. (April 2009 Meeting Abstract Suppl.).

253. Suntharalingam G, Perry MR, Ward S, et al. Cytokine storm in a Phase 1 trial of the anti-CD28 monoclonal antibody TGN1412. N. Engl. J. Med. 2006; 355:1018-1028. [PubMed: 16908486]

254. Gardner K. Cytokine storm and an anti-CD28 monoclonal antibody. N. Engl. J. Med. 2006; 355:2591-2592. [PubMed: 17171819]

255. Fu YH, He JS, Wang XB, et al. A prime-boost vaccination strategy using attenuated Salmonella typhimurium and a replication-deficient recombinant adenovirus vector elicits protective immunity against human respiratory syncytial virus. Biochem. Biophys. Res. Commun. 2010; 395:87-92. [PubMed: 20350532] 
256. Murphy BR, Olmsted RA, Collins PL, Chanock RM, Prince GA. Passive transfer of respiratory syncytial virus (RSV) antiserum suppresses the immune response to the RSV fusion (F) and large (G) glycoproteins expressed by recombinant vaccinia viruses. J. Virol. 1988; 62:3907-3910. [PubMed: 3047432]

257. Kurugol Z, Erensoy S, Aksit S, Egemen A, Bilgic A. Low-dose intradermal administration of recombinant hepatitis B vaccine in children: 5-year follow-up study. Vaccine. 2001; 19:39363939. [PubMed: 11427268]

258. Zhao Z, Smith PJ, Luman ET. Trends in early childhood vaccination coverage: progress towards US Healthy People 2010 goals. Vaccine. 2009; 27:5008-5012. [PubMed: 19524616]

259. Simonsen L, Taylor RJ, Viboud C, Miller MA, Jackson LA. Mortality benefits of influenza vaccination in elderly people: an ongoing controversy. Lancet Infect. Dis. 2007; 7:658-666. [PubMed: 17897608]

260. Walsh EE, Peterson DR, Falsey AR. Is clinical recognition of respiratory syncytial virus infection in hospitalized elderly and high-risk adults possible? J. Infect. Dis. 2007; 195:1046-1051. [PubMed: 17330796]

261. Falsey, AR. RSV in adults: What do we know? What do we need to know? Where are we going?; Presented at: 7th International Respiratory Syncytial Virus Symposium; 12 December 2010; Rotterdam, The Netherlands. (Abstract p81)

\section{Websites}

301. Centers for Disease Control USA. Respiratory syncytial virus infection (RSV). www.cdc.gov/rsv

302. Medimmune discontinues development of motavizumab for RSV prophylaxis indication. http:// pressroom.medimmune.com.

303. The Robinson Library. Edward Jenner. www.robinsonlibrary.com/medicine/medicine/history/jenner.htm

304. Shaw C. Deconstructing RSV vaccine-enhanced disease in cotton rats. www.immunome.org/wpcontent/uploads/2010/11/Shaw_Presentation_Vax_Ren_4.pdf.

305. A randomized, double-blind, placebo-controlled study to evaluate viral shedding of MEDI-559 in healthy 1 to <24 month-old children. http://clinicaltrials.gov/ct2/show/NCT00767416

306. Ghash P. Doubt cast over drug trial safety. http://news.bbc.co.uk/2/hi/health/4989810.stm.

Expert Rev Vaccines. Author manuscript; available in PMC 2012 August 1. 